\title{
Persian in the Villages, or, the Language of Jamiat Rai's Account Books
}

\author{
Samira Sheikh \\ Vanderbilt University, Nashville, Tennessee, USA \\ samira.sheikh@vanderbilt.edu
}

\begin{abstract}
District (pargana)-level land revenue administration in late-Mughal south Gujarat was run mostly by Hindu and Jain family firms which operated within a multilingual environment featuring Gujarati and Marathi as well as Persian. Similar arrangements continued under early East India Company control but, by the 1820s, the British had done away with land-revenue family firms and their contextual multilingualism, replacing them with directly-employed village accountants writing only in Gujarati. This article argues that pargana-level officials' multilingualism and relative autonomy were not an 18th-century aberration but a key feature of Mughal administration, dislodged with difficulty by the British.
\end{abstract}

\section{Keywords}

Mughal - Persian - land revenue - Gujarati - multilingualism - East India Company

In 1773, a couple of months after the British captured the cotton-rich district of Bharuch in south Gujarat, an emissary named James Morley sat down with

1 The Romanisation of Arabic and Persian words in this article follows JESHo's modified IJMES guidance, and a LOC-based common schema adopted for this special issue, for Bengali, Gujarati, Hindi, Marathi and Rajasthani words. To reconcile the two schemas, we have introduced minor variations to the LOC schema to ensure distinct diacritics. In many cases, the same word occurs in multiple languages but is pronounced differently; Romanisation used follows the phonetic context. For the common schema, see pp. 483-5 of this issue. 
two local officials, the desā̄, Jamiat Rai, and the majmū'dār, Lallubhai, to elicit a "more clear and distinct account" of all the taxes that used to be levied from the district during the period of the former nawwābs (nawabs, lords running semi-independent successor states). ${ }^{2}$ After two years of negotiations and an expensive seaborne campaign, Morley's superiors in Surat and Bombay were anxious to know what they could expect to squeeze from their new possession, but, lacking local knowledge and languages, the British were entirely dependent on resident experts such as Jamiat Rai and Lallubhai to help them assess and collect the revenue. Having fled when Bharuch was invaded, these officials were at the time guests of the ruler of neighbouring Baroda who was unwilling to share them with the British. Morley's meeting had taken weeks to negotiate and took place only on condition that the men returned to Baroda after three days. When the meeting finally took place, the two officials were suspicious of the British and of each other and were nervous about the Baroda ruler's spies. $^{3}$ The only information Jamiat Rai would share was his schedule of estimated taxes from six years prior, for the year 1766-67.

Jamiat Rai and Lallubhai's influence in the "little kingdom" of Bharuch depended on their control of the local information order. ${ }^{4}$ When the larger edifice of Mughal governance was crumbling in the 18th century, and there were multiple contenders for power over any given territory, some of the most effective operators were those who were able to control and direct information between the military-fiscal entrepreneurs and the peasantry at the district level. ${ }^{5}$ At the time of Morley's meeting, colonial officials were deeply ignorant

2 James Morley "Informations I have received relative to the Broach Revenues," f. 24, 13th January 1773, Surat Factory Diary [hereafter SFD] 662/1772-73, Maharashtra State Archives, Mumbai [hereafter MSA]. For another study of Morley's report, see S. Hariharan, "Town Revenues and Taxes in Eighteenth Century Gujarat: An English East India Company Document." South Asia Research 23 (2003): 171-9.

3 Morley, "Broach Revenues": ff. 22-4.

4 "Little kingdom" was first used by Bernard Cohn to refer to the lineage-ruled principalities that were left semi-autonomous by overarching empires. B.S. Cohn, "Some Notes on Law and Change in North India." Economic Development and Cultural Change 8/1 (1959): 71-93. See also N. Dirks, "From Little King to Landlord: Property, Law, and the Gift under the Madras Permanent Settlement." Comparative Studies in Society and History 28/2 (1986): 307-33. Chris Bayly's landmark study of the "information order" of British India has little elaboration of such an order in precolonial regimes. C.A. Bayly, Empire and Information: Intelligence Gathering and Social Communication in India, 1780-1870 (Cambridge: Cambridge University Press, 1996).

5 Throughout this article, the Mughal revenue unit pargana is translated as "district." A pargana, a subset of a revenue circle, sarkār, which is itself a component of a süba or province, is also often translated as "sub-district." (Sarkār also means state or government, as will be discussed on p. 721.) In the mid-18th-century Mughal gazetteer Mir'ät-i Aḥmadī, Bharuch was 
about how the countryside was governed, despite the fact that the British had been active in the trading world of south Gujarat for a century and a half. It was not only the British who were ignorant of revenue management; the erstwhile Mughal authorities had been wringing their hands for decades as district-level officials became increasingly autonomous and powerful on the one hand and, on the other, more secretive about what they knew. ${ }^{6}$ As Sumit Guha remarks, "control of records was ownership of power" ${ }^{7}$ and pargana officials were able to manipulate information for three major reasons. First, they were proficient in the prevalent linguistically-organized information order. Persian carried the greatest prestige in this order, but Gujarati, Hindi, Marathi, and English each played their parts along with a plethora of scripts and accounting systems. Pargana officials wielded, or employed scribes who could wield, multiple languages. Second, they were able to control and direct not just the passage but also the legibility of information between languages and genres. By virtue of their state-granted authority, their clerical training, their family business practices, and their Hindu or Jain upper-caste positions, they had access to the courtly texts of literature and epistolography, the legal documents of contracts and decrees, and the commercial language of accountancy, making them accumulators of a vast amount of useful knowledge. The third reason for their ability to manipulate information was their access to "patrimonial" local knowledge, "the deep knowledge acquired by magnates with roots in the villages and the political sympathy which comes from ties of belief, of marriage and from a

listed as both a sarkār and a pargana. Bharuch sarkār comprised 13 parganas, one of which was Bharuch pargana which contained 18 o villages as well as a port. The villages and town drew a revenue of 15,233,754 dāms (dām was a low-denomination coin. 40 dāms = 1 rupee) and the port 950,00o dāms. 'Ali Muhammad Khān, Mirāt-i Aḥmadī: Supplement. Trans. S.N. Ali and C.N. Seddon (Baroda: Oriental Institute, 1928): 175 .

6 An account from 1725 says that revenue officials from Gujarat had stopped submitting taxes and reports to the central administration. See S. Khan, "An Important Persian Source on Mughal Gujarat-Diwanu Khatanu Pustak." Historicus:Journal of Pakistan Historical Research 46 (1998): 56. An 1807 report on local finances in Bharuch, citing a Persian document, mentions Mughal emperor Aurangzeb's efforts to rein in district tax officials. G.L. Prendergast and W. Steadman, "Appendix 61. [to the Report of Messrs. Prendergast and W. Steadman (Revenue Commissioners) on the Local Institutions and Fiscal Resources of the District of Broach]: Statement of Allowances Claimed by the Mujmudars, Remarks Thereon by Govt, Explanations by the Baroda Resident and Observations by the Revenue Commission (of 27-31 May 1807)," Revenue Department Diary [hereafter RDD] 59/1808, MSA.

7 S. Guha, "Rethinking the Economy of Mughal India: Lateral Perspectives." Journal of the Economic and Social History of the Orient 58/4 (2015): 553-4. Guha thinks it likely that the best data on village yields might come from places where "autochthonous rulers sustained by clan followings and aided by scribal-mercantile adjuncts governed for long periods." In Bharuch, the "scribal-mercantile adjuncts" were themselves long-entrenched brokers of local power. 
sense of inhabiting the same moral realm." ${ }^{8}$ By switching between linguistic registers and genres, and by strategically proffering or withholding information, they were able to render their activities indispensable yet opaque. The most politically astute of such officials wielded considerable power in these times, in Gujarat and beyond.

Parganas preceded the Mughals. John Richards argued that parganas were the "primary building blocks of political control" in the Indian countryside and often functioned as miniature kingdoms led by local lineages which exerted claims to taxes, tributes, and labor from subordinate inhabitants. From the start of the Mughal empire, the challenge was to manage rivalries between pargana-based lineages and to incorporate them into the hierarchy of the empire. Under the Mughal emperor Akbar in the late 16th century, contiguous parganas were grouped into revenue circles (sarkärs) with karorīs, or revenue officials, deputed to survey and measure the fields in each revenue circle for the production of data for revenue assessment. Pargana officials, whether related to the local ruling lineage or not, often retained their powers and received percentages of the revenue and revenue-free grants in return for their services in collecting and recording the revenue. The pargana thus functioned as a "hard-shelled structure" that the Mughals tried, and only partially managed, to penetrate. ${ }^{9}$

In a similar vein, East India Company (EIC) officials trying to interpret local governance and adapt it to their needs struggled with pargana politics, in particular the accessibility, languages, scripts, legibility, and categories of record-keeping. The efforts of early colonial officials to decipher revenue records and render them legible went along with their efforts to acquire a predictable, measurable revenue stream. ${ }^{10}$ Initially they had limited success on both counts, continuing to require the services of district officials to whom they constantly feared losing funds and credibility, but, several decades after Morley's initial encounter with Jamiat Rai's accounts in 1773, the British constructed a system to impose transparency and order on revenue practices. Returning to Bharuch in 1803 after a two-decade-long hiatus when they were forced to give Bharuch up to the Marathas, the Company launched, from 1812, detailed surveys and censuses of all its possessions in south Gujarat "in its attempt to identify the Ricardian rent it believed was its right as sovereign to

8 Bayly, Empire and Information: 55.

9 J.F. Richards, The Mughal Empire (Cambridge: Cambridge University Press, 1993): 82.

10 J.C. Scott, Seeing Like a State: How Certain Schemes to Improve the Human Condition Have Failed (New Haven: Yale University Press, 1998), 13-5. 
collect."11 The linguistic complexity and ambiguity controlled by Mughal-era district officials, the desāis and majmū'dārs, and their links to village leaders (patels) were set aside by appointing salaried village-level accountants (taläțiss), to report directly to newly-appointed British district collectors. Prior systems of record-keeping were discarded as inefficient and illegible. Captain Barnewall, the assistant collector of Kheda, said in 1816 that the village accounts kept by patels, or headmen, "were in most cases framed in a way so complex and unsatisfactory as to be entitled to little or any confidence."12 In the new regime, talāțīs were required to maintain detailed village registers (moje jarîf) as well as kalambandhī volumes (from Persian qalambandī, signed document or agreement) to be stored in district record offices.

There was little multilingualism or opacity about the jarif or kalambandhī books. ${ }^{13}$ Ever since they were produced, they were referred to as "vernacular" records, which in this context meant that they were written in the Gujarati language in the Nagari script. While I have not examined the kalambandhi records of Bharuch, should they survive, there is one survey of Kajipura village from Bharuch district in 1820, written in Gujarati and annotated in English, demonstrating the language, script, and categories of information sought by British surveyors at this point, that I will examine closely in the latter part of this article. The survey of Kajipura demonstrates that by elevating village accountants and their Gujarati records and making them directly subservient to British collectors, the British effectively snuffed out the multilingual, cryptic, "patrimonial" authority of late-Mughal pargana officials such as Jamiat Rai and Lallubhai and imposed a tidy, utilitarian order on revenue practices. What changed between 1773 and 1820 that allowed the British to penetrate and overhaul the hard-shelled pargana? The transition from Jamiat Rai's enigmatic accounts in 1773 to the "vernacular" jarif book of Kajipura in 1820 was not a

11 M.J. Frost, "Coping with Scarcity:Wild Foods and Common Lands: Kheda District (Gujarat, India), 1824/5." Indian Economic and Social History Review 37/3 (2000): 295-329.

12 A.M. Shah et al., "Early Nineteenth Century Village Records in Gujarat." Gujarāta Saṃśodhana Maṇdalanum Traimāsika:Journal of the Gujarat Research Society 25 (1963): 128, quoting "Accompaniment to Kaira Collector's Letter to Chief Secretary, 20-8-1816," RDD 85/1816, MSA. For other examples of British unease with local officials' records, see Guha, "Rethinking the Economy": 556 .

13 In a series of articles, including the one in the previous footnote, A.M. Shah and his associates described kalambandhī and jarîf records dating from the 1820 s from Kheda district (north of Bharuch). Similar records were later studied by Alice Clark and Marcia Frost, among others. See, for instance, Frost, "Coping with Scarcity" and A. Clark, "Changes in Kinship and Marriage in Two Selected Areas in India: A Study Based on Female Infanticide Records During the Nineteenth Century." Ph.D. thesis: University of Delhi (1976). 
mere bureaucratic reorganization: it offers an index to the political, legal, and linguistic shifts that accompanied the establishment of British rule.

\section{$2 \quad$ Jamiat Rai's Account Books}

Writing about India in the late 18 th century can be tantalizing. The fact that a lot of material survives seduces one into thinking one can reach back and figure out almost anything. After I read Morley's letter to his superiors in Bombay, containing tables of local revenues in English, I immediately re-read it to see if he described Jamiat Rai's account book in any detail. To my disappointment, all he said was "I have the Honour to Enclose you Sundry Papers containing the Informations I have received relative to the Broach Revenues."14 Like most other non-English correspondence and documents of the era, Jamiat Rai's account books were not preserved in the Company's archives. I do not know if Morley ever saw them. Nor do I know what language they were in.

In the late 18th century, as the Mughal empire gave way to successor states and European trading companies, Mughal revenue practice was becoming disarticulated from actual Mughal government. One location where such separation was taking place was Bharuch, a former Mughal revenue unit in south Gujarat ruled for half a century until 1772 by a lineage of nawabs, descendants of a Mughal-appointed jāgīrdār (land-right holder), who claimed a degree of independence from the Mughals while maintaining Mughal-style political and revenue-gathering practices. ${ }^{15}$ A desirable black-soil territory situated on the north bank of the Narmada river where it opened to the sea, Bharuch was made wealthy by cotton, ghee, and manufactures. It had a flourishing and taxable port and was a key way-station on the road from north India to Surat. Since 1756, the nawabs had shared their revenues (and sovereignty over Bharuch) with the neighboring Marathas of the Gaekwad family. When the British captured Bharuch in November 1772, they retained much of prevalent Mughal administrative convention, going to considerable trouble to retain the principal officials who ran its land revenue infrastructure.

Of the pargana-level officials involved in the assessment and collection of land revenue in Bharuch, south Gujarat, the most prominent were the

\footnotetext{
14 Morley, "Broach Revenues": ff. 30-1, 31st January 1773.

15 Neighboring rivals continued to refer to the Bharuch rulers as faujdārs (fort or garrison commanders) until they were overthrown, even though Nizam al-Mulk, the governor of Gujarat, and the Mughal emperor Ahmad Shah (r. 1748-54) had endorsed the title of nawab.
} 
majmū'dārs, keepers or auditors of tax records, and the desāīs, in charge of the revenue assessment, jama .16 Both offices had been active in Gujarat since the reign of the Mughal emperor Akbar (1556-16o5), if not earlier. Majmū'dārs and desāīs in Bharuch — and elsewhere in Gujarat — received revenue-free (in'âm) grants of land in return for their services and were expected to serve as checks and balances on one another. In practice, the actual roles of majmū'dārs and desāīs were not clearly distinguished: the two officials tended to work out a competitive coexistence. ${ }^{17}$ Whether or not these positions were originally designed to be hereditary, by the 176 os they were held by two Hindu families in Bharuch who functioned as family firms, presenting themselves as embodiments of the state to the peasants while also functioning as private corporate entities working in pursuit of their own interests. ${ }^{18}$ I have written previously that the proprietors of land revenue family firms were not strictly government employees, in that their income and influence did not derive exclusively from state patronage. Nevertheless, they represented the state (sarkār) to other entities such as farmers, moneylenders, and zamīndārs. ${ }^{19}$ It was their sarkārī

16 B.R. Grover, "The Position of Desai in the Pargana Administration of Subah Gujarat under the Mughals." Proceedings of the Indian History Congress 24 (1961): 15o. It is worth noticing that the majmū'dār possessed a Persianate title while the desāîs title was Gujarati (or perhaps Marathi in origin, says Grover, 154). In the Marathi-writing world, a desāī was generally a land-right holder on the lines of a zamīndār. In Gujarat, the desāìs role was closer to the official called qānūngo or sarrishtadār elsewhere in the Mughal empire although he was generally in possession of local land rights too. In 1773, shortly after Morley's letter, there were reported to be 14 desāis in Broach pargana. (Broach Factory Diary 259/1773: f. 253.) In 1805, there were only 4 "principal" desāis in Bharuch pargana, of whom Daulat Rai, the son of Jamiat Rai, was described as the most prominent. RDD 44/18०5: f. 301.

17 Grover, "Position of Desai": 15o, citing 'Alī Muhạmmad Khān and Mịthālāl Kāyasth, Khātima-yi Mir'āt-i Ahmmadī (Baroda: Oriental Institute, 1930): 228. During the Gujarat sultanate, pargana officials ('ummāl-i parganāt) were similarly appointed to balance one other, with one official being a servant (banda) of the sultan and the other belonging to a local lineage. Sikandar b. Muhammad, Mir'at-i Sikandarī, ed. S.C. Misra (Baroda: M.S. University of Baroda, 1961): 58.

18 This is not quite the same as ijära, revenue farming, which, as Sudev Sheth has argued, was a diversification of the state into the emerging land revenue marketplace by granting temporary contractual rights in return for advance rent. S. Sheth, "Revenue Farming Reconsidered: Tenurial Rights and Tenurial Duties in Early Modern India, ca. 1556-1818." Journal of the Economic and Social History of the Orient 61/5-6 (2018): 878.

19 S. Sheikh, "Jibhabhu's Rights to Ghee: Land Control and Vernacular Capitalism in Gujarat, circa 1803-10," Modern Asian Studies 51/2 (2017): 352. David Curley uses the term "managerial elites" to emphasize the importance of accountancy skills in their portfolios. D.L. Curley, "Styles of Mastery of a Calcutta Brahman Family: Krishnachandra Ghoshal's Pilgrimage to Gaya, Kashi and Prayag, 1769, in Vijayram Sen's Tìrthamangala." Indian Economic and Social History Review 57/1 (2020): 79. 
"state-ness" that gave them the credibility to function. As tax assessors and auditors, the desāi and majmū'dār firms were the points of contact between the (transferable) Mughal office-holders (jāgīrdārs) and (stationary) village officials and other functionaries. The British inherited their services-and networks - from the Mughal-style administration of the nawabs.

After their meeting with Morley, and during the subsequent decade of British control over Bharuch (1772-83), Jamiat Rai and Lallubhai held on to their local knowledge; there is no evidence that they ever gave up their account books for British inspection. Lallubhai in particular worked closely with British officials, virtually resuming his position as the Bharuch majmū'dār, but did not allow close scrutiny of his methods, a posture that caused chagrin among certain British officials who harrumphed about his outsize influence and saw his evasiveness as incapacity. When, in 1776 , William Perrott embarked on the first comprehensive survey of Bharuch, grumbling that the desāis and the majmū'dārs were so ignorant of the lands they governed that they had "never seen an account of the land said to belong to each," part of his irritation was at local officials' ready access to information that was impenetrable to him. ${ }^{20}$ Even when the British obtained some of the information within these booksas Morley did - their language, script, and classification schemes could remain opaque. If I have not been able to find Jamiat Rai's accounts, it is by design. The land revenue family firms did not intend for outsiders to see their records.

\section{Mughal and Pre-Mughal Languages of Revenue}

As a pargana-level revenue official in a Mughal successor state that had formerly been a Mughal revenue district, did Jamiat Rai write in Persian or did he keep accounts in Gujarati? If the former, did he use Mughal siyā $q$ notations?21 If the latter, what script did he use-the Nagari with which we associate Gujarati today, or one of the commercial scripts used by Gujarati business

$20 \quad$ G.W. Forrest, ed. Selections from the Letters, Despatches, and Other State Papers, Preserved in the Bombay Secretariat, vol. 2, Home Series (1887): 180. For others, such as customs officer James Forbes, Lallubhai was an intriguing, even romantic, figure, whose arcane knowledge included the ability to cure snakebite. James Forbes, Oriental Memoirs, vol. 3 (London: White, Cochrane, And Co., 1813): 248-9.

21 See N. Haider, "Language, Caste and the Secretarial Class in Mughal India." In The Evolution of a Nation Pre-Colonial to Post-Colonial: Essays in Memory of R.S. Sharma, ed. D.N. Jha (Delhi: Manohar, 2014): 254, for a description of the siyāq accounting system introduced in the 16th century. For a history of siyāqat beyond South Asia, see M. Bagheri, "'Siyāqat' Accounting: Its Origin, History, and Principles." Acta Orientalia Academiae Scientiarum Hungaricae 51/3 (1998): 297-301. 
people? Further, what was the nature of his literacy — did he personally write in his account books or did he dictate to a clerk? In the absence of his records, historical practice will have to provide clues.

Under the Chaulukyas of Gujarat (ca. 940-1244), revenue records were likely to have been in Sanskrit - the "vernacular" or "Jain" Sanskrit of medieval texts-or in early Gujarati. ${ }^{22}$ Once Gujarat came under Delhi sultanate control in 1297, revenue records may have been transmitted in Persian, but probably continued to be recorded by local Hindu or Jain officials in Sanskrit or Gujarati. Letter templates preserved in an undated but probably pre-15th-century compendium of form-letters, Lekhapaddhati, were mostly in vernacular or business Sanskrit, some containing Gujarati fragments and phrases. ${ }^{23}$ This dual linguistic system likely persisted under the Gujarat sultans in the 15th and early 16th centuries. Pre-Mughal stone inscriptions in Persian, recording donations, grants, or transactions, often had a few lines in Gujarati. ${ }^{24}$

In north India, a few surviving Persian-Kaithi documents suggest a phase of documentary bilingualism that was probably the norm for the same period. ${ }^{25}$ In the early 16th century, the Afghan ruler Sher Shah Sur appointed two sets of district officials, one to maintain records in Persian ( färsì-nawiss) and the other in the local language, Hindi (hindi-nawis), a measure which Najaf Haider sees as an important effort to expand "political and fiscal" control at the district level. ${ }^{26}$ Sher Shah's increased emphasis on Persian as the language of upper administration continued under the third Mughal emperor Akbar (r. 15561605). Sometime between 1582 and 1584, Raja Todar Mal, senior financial administrator to Akbar, decreed that all administration was to be in Persian

22 On varieties of Sanskrit, including in medieval Gujarat, see M.M. Deshpande, "Sanskrit in the South Asian Sociolinguistic Context." In Language in South Asia, ed. B.B. Kachru, Y. Kachru, S.N. Sridhar (Cambridge: Cambridge University Press, 2008) and M.M. Deshpande, Sanskrit \& Prakrit: Sociolinguistic Issues (Delhi: Motilal Banarsidass, 1993), especially chapter 3, "On Vernacular Sanskrit:The Gìrvāṇavāñmañjarī of Dhuṇ̣irāja Kavi."

23 I. Strauch, Die Lekhapaddhati-Lekhapañcasika: Briefe und Urkunden im mittelalterlichen Gujarat: Text, Übersetzung, Kommentar:Glossar (Sanskrit-Deutsch-Englisch) (Berlin: D. Reimer, 2002).

24 S.C. Misra, "Some Aspects of the Economy of the Sultanate of Gujarat." Proceedings of the Indian History Congress 43 (1982): 244, 246. On bilingual inscriptions, see S. Sheikh, "Languages of Public Piety: Bilingual Inscriptions from Sultanate Gujarat, c. 1390-1538." In After Timur Left: Culture and Circulation in Fifteenth-Century North India, ed. F. Orsini and S. Sheikh (New Delhi: Oxford University Press, 2014): 193, 195, 202.

25 M. Mohiuddin, The Chancellery and Persian Epistolography under the Mughals, from Babur to Shah Jahan, 1526-1658 (Calcutta: Iran Society, 1971): 28; M.M. Shafi, "Three Old Documents." Proceedings of the Idara-yi Ma'arif-i Islamia (Lahore, 1936): 281-5.

26 Haider, "Language, Caste and the Secretarial Class in Mughal India": 249. 
and in the "Iranian style," and to be staffed by a cadre of Iranian and Hindu clerks, secretaries, and scribes. ${ }^{27}$ It is generally accepted that after this decree, Persian became the dominant language of government throughout the Mughal realm and persisted in that capacity into early colonial India until the British made concerted attempts to replace it with English from the 183 os onwards. ${ }^{28}$ While Persian became the language of court and the Mughal elite, there is evidence that Persian language skills, in the form of "pragmatic literacy" or "Persographia," came to be found even among village-level revenue officials. ${ }^{29}$ The vast bulk of surviving official documentation from the directly-governed parts of the Mughal empire, ranging from royal or courtly orders (farmāns) to deeds of sale, is in Persian. Nevertheless, most Mughal officials and scribes continued to be multilingual.

Although Persian became the dominant language of Mughal documentation, it is unlikely that it was the only official language, especially in sub-provincial revenue record-keeping. Insisting that Persian was the only language of government is a way of asserting that the Mughal state — and its chosen language, Persian-became thoroughly indigenized and penetrated deep into Indian society. ${ }^{30}$ If Jamiat Rai's books were in Persian, they would be evidence of

27 Haider, "Language, Caste and the Secretarial Class in Mughal India": 25o; I. Habib, The Agrarian System of Mughal India, 1556-1707 (New Delhi: Oxford University Press, 2000): 324 , n. 45. For an argument that the early Mughals' efforts to rationalize revenue collection were intrusive, "frightfully efficient," and in a "spirit of verification and scepticism," see A. Anooshahr, "Author of One's Fate: Fatalism and Agency in Indo-Persian Histories." Indian Economic and Social History Review 49/2 (2012): 220-2.

28 On the transition to English, see, for instance, K. Prior, L. Brennan, and R. Haines, "Bad Language: The Role of English, Persian and Other Esoteric Tongues in the Dismissal of Sir Edward Colebrooke as Resident of Delhi in 1829." Modern Asian Studies 35/1 (2001): 75-112, and T. Rahman, "Decline of Persian in British India." South Asia: Journal of South Asian Studies 22/1 (1999): 47-62. The records of the Anglicist-Orientalist debate are in M. Moir and L. Zastoupil, ed. The Great Indian Education Debate: Documents Relating to the Orientalist-Anglicist Controversy, 1781-1843 (Richmond: Curzon, 1999).

29 M. Alam, "The Pursuit of Persian: Language in Mughal Politics." Modern Asian Studies 32/2 (1998): 328 . On the intrusion of written documents into the locality and consequent "pragmatic literacy," see F. Hasan, "Property and Social Relations in Mughal India: Litigations and Disputes at the Qazi's Court in Urban Localities, 17th-18th Centuries." Journal of the Economic and Social History of the Orient 61/5-6 (2018): 858-9. On "Persographia," a view of Persian as a widespread written contact language that did not necessarily imply a shared culture or spoken facility, see N. Green, The Persianate World: The Frontiers of a Eurasian Lingua Franca (Berkeley, University of California Press, 2019): 4-5. An important plea for multilingual approaches to oral and documentary cultures can be found in F. Orsini, "The Multilingual Local in World Literature." Comparative Literature 67/4 (2015): 345-74.

$30 \quad$ For a critique of "integrationist" models that see the Mughal imposition of Persian as a proto-nationalist move, see S. Guha, "Transitions and Translations: Regional Power and 
the Mughal empire's reach. If they were in Gujarati, in a commercial script, they could be evidence that the dominant Mughal language, and thereby the Mughal state, remained external to certain aspects of Indian political life. An exclusive emphasis on Persian risks masking a lively and context-sensitive documentary multilingualism that persisted through the 17th century and into the 18th. Perhaps we should cast the net wider; important new work is now challenging the notion of archives as spatially defined repositories and suggesting, instead, that we imagine more capacious circumstances of documentary production and memorialization. ${ }^{31}$ Certainly, the futile search for large colonial-style "official" archives from the pre-British era has meant that household-held records, whether in the possession of land right-holders or information-specialist family firms such as those of Jamiat Rai and Lallubhai, have remained largely unseen and unremarked.

In advance of thorough study, it is premature to assume that district-level revenue records were invariably in Persian. In the Mughal heartlands of north India, there is plenty of evidence that "Hindi" record keeping was not abandoned. Of the large collection of orders and sale deeds from Vrindavan, a significant proportion is in Braj, in the Nagari script, or in Braj and Persian. ${ }^{32}$ More pertinently, an appointment order translated by J.F. Richards enjoined provincial officials to collect in each season "the account papers of the several villages of every subdistrict (pargana), and translate them into Persian," and then to send the translated accounts on to the emperor. ${ }^{33}$ The author of Richards' early 18th-century administrative manual evidently did not expect village records to be kept in Persian. Outside directly-governed Mughal

Vernacular Identity in the Dakhan c. 1500-180o." Comparative Studies of South Asia, Africa, and the Middle East 24/2 (2004):13. Pushing against Kumkum Chatterjee's contention that Persianization in Bengal represented a "complementary cultural trajectory" to regional Brahmanism, David Curley proposes a closer look at new "forms of sociability" to theorize multilingualism. See K. Chatterjee, The Cultures of History in Early Modern India (Delhi: Oxford University Press, 2009): 235-7, and Curley, "Styles of Mastery of a Calcutta Brahman Family": 78-9.

31 Chatterjee, Negotiating Mughal Law: 31-4. A provocative argument to consider archiving as practice rather than place may be found in K. Hirschler, "From Archive to Archival Practices: Rethinking the Preservation of Mamluk Administrative Documents." Journal of the American Oriental Society 136/1 (2016): 1-28.

32 I. Habib, "A Documentary History of the Gosāin of the Chaitanya Sect at Vrindāvan." In Govindadeva: A Dialogue in Stone, ed. M. Case (New Delhi, Indira Gandhi National Centre for the Arts, 1996): 131-3.

33 J.F. Richards, Document Forms for Official Orders of Appointment in the Mughal Empire: Translation, Notes and Text (Cambridge: E.J.W. Gibb Memorial Trust, 1986): 33. For an important discussion of multiple languages and scripts in documentary culture, see Chatterjee, Negotiating Mughal Law: 164-7. 
territories, revenue records were often not in Persian. In the Rajput kingdoms, for instance, revenue records were kept in various local languages, albeit deeply imbued with the Mughal state's Persian vocabulary. ${ }^{34}$ The Adil Shahi rulers of Bijapur used written Marathi for local government, including revenue collection and judicial matters, as did the Nizam Shahis. The Qutb Shahis of Golkonda often issued bilingual (Persian and Telugu) edicts, while local revenue papers were largely in Telugu. ${ }^{35}$

In Gujarat, as in other parts of the Mughal empire, most of the official paperwork that has been archived and catalogued in public collections is in Persian, although there are few studies thus far of original correspondence and documents bearing seals, signatures, and other marks of having passed through official hands, still less of officials' revenue records. ${ }^{36}$ Nevertheless, it is clear that certain genres of official documents could be in languages other than Persian. A set of land records from Ahmedabad, for instance, suggests that a proportion of sale deeds of land (khatapatras) were in Gujarati, in the Nagari script, while a few were in Persian. ${ }^{37}$

Outside the state bureaucracy, Gujarati business firms kept records in Gujarati, and had done so since medieval times. A few surviving papers from the Geniza records suggest early commercial use of Gujarati, as do 17th-century inscriptions from Socotra. ${ }^{38}$ Hundīs, or promissory notes, and account books, were

34 See, for instance B.L. Bhadani, Peasants, Artisans and Entrepreneurs: Economy of Marwar in the Seventeenth Century (Delhi: Rawat Publications, 1999); N. Prasad Sahai, Politics of Patronage and Protest: The State, Society, and Artisans in Early Modern Rajasthan (New Delhi: Oxford University Press, 2006), and Divya Cherian, "Ordering Subjects: Merchants, the State, and Krishna Devotion in Eighteenth-Century Marwar." Ph.D. dissertation: Columbia University (2015).

35 Guha, "Transitions and Translations": 13-4; R.M. Eaton, "The Rise of Written Vernaculars: The Deccan, 1450-165o." In After Timur Left: Culture and Circulation in Fifteenth-Century North India, ed. F. Orsini and S. Sheikh (New Delhi: Oxford University Press, 2014): 12O-1; and M. Alam, "The Culture and Politics of Persian in Precolonial Hindustan." In Literary Cultures in History: Reconstructions from South Asia, ed. S. Pollock (Berkeley: University of California Press: 2003): 131-98.

36 Farhat Hasan's revealing study of a set of judicial documents from Gujarat pays little attention to the materiality of the documents. F. Hasan, State and Locality in Mughal India: Power Relations in Western India, c. 1572-1730 (Cambridge: Cambridge University Press, 2004).

37 M. Mehta, "Khatapatras as a Source of Urban History." Indian Archives 30 (1981): 21-9.

38 For a Geniza fragment likely to be in Gujarati, see https://www.lib.cam.ac.uk/collections/ departments/taylor-schechter-genizah-research-unit/fragment-month/fragment-month -10-2 (accessed 6 January, 2020). For a study of 17-18th-century Gujarati inscriptions in Socotra, see B. Shelat, “The Gujarati Stone Inscriptions from Rās Howlef (Socotra).” In Foreign Sailors on Socotra: The Inscriptions and Drawings from the Cave Hoq, ed. I. Strauch (Bremen: Hempen Verlag, 2012): 407-32. 
often in Gujarati. Some correspondence and paperwork was carried out in commercial scripts, such as versions of the Mahäjanī script used throughout northwestern India. ${ }^{39}$ For the 18th century, an extraordinary collection of documents belonging to a Baroda-based banking firm gives us some idea of how documents were organized on multilingual lines (or were themselves multilingual). The Haribhakti papers include account books, ledgers, deeds, state documents, and correspondence from the early 18 th to the early 20 th century. ${ }^{40}$ Correspondence was often in Persian, while documents such as account books, most of which were not intended for the eyes of outsiders, were in Gujarati or Marathi, written in the Mahājanī-Munḍ̂̀ or Modì script, two of the many commercial scripts of western India. ${ }^{41}$ Yet other documents were in a Nagari-script rendering of Gujarati. Accounts were mostly in the Gujarati system, rather than the siyāq accounts mandated by the Mughal bureaucracy. The collection of Haribhakti papers remains in need of thorough study, but preliminary surveys confirm the multilingualism of the family's transactions.

The welcome growth in the literature on Mughal-era revenue officials, scribes, and clerks has brought out the challenges in drawing precise distinctions between these occupations. It is clear that there were significant variations of status, function, and linguistic ability among such individuals, even those who bore the same titles. While some revenue officials kept their own books, others delegated record-keeping to specialist scribes. ${ }^{42}$ Certain Persian-trained clerks achieved renown for the literary merit of their writings, while others possessed

39 C. Ray Miller, "Devanagari's Descendants in North and South India, Indonesia and the Philippines." Writing Systems Research 6/1 (2014): 10-24.

40 Although preliminary categorization was done by G.D. Sharma, the Haribhakti collection awaits thorough study. See, for instance, G.D. Sharma and M.A. Patel, "State and Indigenous Business in the Urban Economy of Gujarat, c. 1770-1810: A Study of the Haribhakti Records." In Urbanization in Western India, ed. M. Mehta (Ahmedabad: Gujarat University, 1988): 59-71, and G.D. Sharma, "Economy and Society of Rural Gujarat in the Second Half of the 18th Century: A Study based on the Haribhakti Papers." Proceedings of the Indian History Congress 45 (1984): 367-74.

41 Such scripts include vāniāā (from vānīo, trader), sarräfí (from șarrāâf, banker), or boḍīā (from bōdum, clipped or shorn). A.S. Asani, "The Khojkì Script: A Legacy of Isma'ili Islam in the Indo-Pakistan Subcontinent." Journal of the American Oriental Society 107/3 (1987): 439, and Sharma and Patel, "A Study of the Haribhakti Records": 61.

42 Early 19th-century representations of tax officials often show them accompanied by a professional munshī or scribe. See, for example, the 1816 portrait, from the Stuart Cary Welch collection, of William Fraser's diwān Mohan Lal accompanied by his munshī Fuzl Uzeem reproduced in W. Dalrymple, ed., Forgotten Masters: Indian Painting for the East India Company (London: The Wallace Collection, 2019): 167. 
only rudimentary skills in copying, letter-writing or accountancy. ${ }^{43}$ Some scholars have attempted to nuance these distinctions with compound terms such as "scribal-mercantile adjuncts," "managerial elites," "proto-bureaucrats," and "portfolio capitalists" for the kind of revenue officials and local magnates who had been entrepreneurial in expanding their repertoires and political influence while others have chosen to use self-identifiers that appear in the texts. ${ }^{44}$ In spite of the careful work done thus far, it is not always possible to assess an individual's literacy or numeracy based on their job title or to figure out what languages they actually used.

For the context I have described here, more work needs to be done to establish whether officials such as Jamiat Rai possessed scribal and accountancy skills themselves or whether bookkeeping and correspondence were carried out by clerks in their employ. The ability to speak a language did not, at this time, necessarily mean literacy but even a basic or functional grasp on the language allowed elite men to guide the productions of specialist munshīs. ${ }^{45}$

43 There is a considerable literature on Mughal-era scribes, many of whom were nonMuslims. See, for instance, R. Kinra, Writing Self, Writing Empire: Chandar Bhan Brahman and the Cultural World of the Indo-Persian State Secretary (Berkeley, University of California Press, 2015): 292-4; N. Haider, "Norms of Professional Excellence and Good Conduct in Accountancy Manuals of the Mughal Empire." International Review of Social History $5^{6}$ (2011): 263-74; R. O'Hanlon, "The Social Worth of Scribes: Brahmins, Kāyasthas and the Social Order in Early Modern India." Indian Economic and Social History Review 47/4 (2010): 563-95; M. Alam and S. Subrahmanyam, "Witnesses and Agents of Empire: Eighteenth-Century Historiography and the World of the Mughal Munshī." Journal of the Economic and Social History of the Orient 53/1-2 (2010): 393-423; S. Guha, "Serving the Barbarian to Preserve the Dharma: The Ideology and Training of a Clerical Elite in Peninsular India c. 1300-180o." Indian Economic and Social History Review 47/4 (2010): 497-525; and M. Alam and S. Subrahmanyam, "The Making of a Munshi." Comparative Studies of South Asia, Africa, and the Middle East 24 (2004): 61-72. On revenue officials and scribes over a comparable period in north India, see H. Bellenoit, "Between Qanungos and Clerks: The Cultural and Service Worlds of Hindustan's Pensmen, c. 1750-1850," Modern Asian Studies 48/4 (2014): 872-910. On such officials in Gujarat, see Grover, "The Position of Desai."

44 Guha, "Rethinking the Economy of Mughal India": 553-4; Curley, "Styles of Mastery of a Calcutta Brahman Family:" 79; Bellenoit, "Between Qanungos and Clerks": 889; S. Subrahmanyam and C.A. Bayly, "Portfolio Capitalists and the Political Economy of Early Modern India." Indian Economic and Social History Review, 25/4 (1988): 401-24.

45 For instance, the Persian letters composed by scribe Krishan Sahai in the 177os were shaped and organized by his employer, Frenchman Antoine-Louis Henri Polier. See M. Alam and S. Alavi, A European Experience of the Mughal Orient: The Ijjāz-i Arsalānī (Persian Letters 1773-1779) of Antoine-Louis Henri Polier (New York: Oxford University Press, 2001): 17. Closer to our context, Nawab Mu'azzaz Khan of Bharuch (r. 1768-72) was careful to have letters to his neighbor and rival, Fatehsinhrao Gaekwad of Baroda, written in Marathi, as he knew Fatehsinhrao did not know Persian. S.M. Ahmad, History of the Nawābs of Broach 
From another source I know that Jamiat Rai's colleague and rival Lallubhai knew multiple languages - Hindi, Marathi, and Persian —in addition to his native Gujarati, and that he understood some English. He prized Persian literature and "those who revealed literary talent." In the 179os, he commissioned a compilation of official Persian letters whose name, Majmü'a-yi dānish or compendium of wisdom, was a play on his title of majmū'dār. ${ }^{46}$ The Majmü'a-yi dānish contains a number of letters sent by or to Lallubhai, suggesting that he, like other officials of his rank, communicated with jāgīrdārs and other functionaries of the Mughal order through correspondence in Persian dictated to munshīs. I know much less of Jamiat Rai's linguistic talents, but, considering he was of comparable status and background, it is fair to imagine he was also multilingual, with some grasp of Persian in addition to Gujarati, Marathi, and Hindi. While bureaucratic correspondence was in Persian (or in Marathi, if dealing with the Marathas), dealings with village-level officials including patels (village headmen), talāțis (accountants), and mehtās (scribes) must have been in Gujarati, whether verbally or in writing. If we are to believe William Perrott who noted in 1776 that the district officers rarely visited the lands whose taxes they administered, communication between the Bharuch-based desāī and majmū'dār and the villagers must have been by couriers carrying verbal or written missives in Gujarati.

Having conducted negotiations with the nawab for a year before this meeting, Morley was already acquainted with Lallubhai, and the three men are likely to have had enough common linguistic resources to communicate verbally or had interpreters or scribes to help. As Morley does not mention reading or copying the records personally, perhaps Jamiat Rai or his munshì read the accounts aloud, including the long lists of figures. If so, Morley's summary is a transliteration of what he heard followed by a translation into English, which would mean we are at several removes from the written contents of Jamiat Rai's books. As the language of Jamiat Rai's books cannot be determined, we now turn to the content he shared with Morley for clues to the linguisticallyinflected organization of revenue information.

(Based on the Persian Manuscript Majmū'ā-e-Dānish). (Delhi: Dept. of Persian, University of Delhi, 1985): 156, citing letter 112/3 of the Majmü'à-i Dānish.

46 The compiler of the nawab's letters, Kishor Das Munshi, describes Lallubhai's linguistic skills thus: "He was a remarkable linguist and could reply to the peoples of different nations and tribes in their own languages. People speaking different languages, Hindi, Marathi or Persian, were all amazed at his mastery of their languages." Kishor Dās Munshī, Majmu'a-yi Dānish, ed. S. Maqbul Ahmad, partial trans. Saeed Hasan (Allahabad: Ram Narain Lal, 1957): 9. 
The British had turned their sights on Bharuch because of its reputation for wealth, largely from land revenue and customs dues, and, at the start of British rule in 1772 , the newly captured territory seemed full of promise. After the conquest, expectations were scaled down. The Bharuch expedition had been sold to the Company's directors based on a wildly optimistic expectation of 7,00,000 rupees of annual returns. Now, they were willing to accept a more modest estimate of about Rs. 3,20,00o from a year of good harvest. When, in January 1773, Morley sat down with Lallubhai and Jamiat Rai to elicit a summary of the taxes that used to be levied from the district during the period of the late nawabs, he was hoping that it was not already too late to assess and collect taxes on the past season's crops.

As we shall see, Morley's report shows that local land-revenue practice encompassed both Persian and Gujarati vocabulary, comprising normative Mughal-Persianate legal terms as well as indigenous Gujarati jargon. First we learn that the Bharuch territory contained 179 villages, of which eight belonged entirely to the Gaekwads. ${ }^{47}$ Three were deserted. Nine of the 179 villages were alienated to prominent local individuals. These included the majmu'dār Lallubhai and the desāī Jamiat Rai who each possessed an in'ām village, paying no taxes to either the Gaekwads or the nawab. The remaining seven villages were given in hereditary waziffa grants to Muslim clerics who paid no taxes to the nawab but did pay the Gaekwads. ${ }^{48}$ Such tax exemptions were reported in the Mughal state's Persian vocabulary: in'ām, or gift, wazịfa, or stipend. Leaving aside the villages that were exempted or deserted, or which belonged to the Gaekwads, Morley listed 159 villages that paid regular land revenue, the proceeds of which were divided between the Gaekwads and the nawab in the proportion 3:2.

Jamiat Rai's schedule of estimated taxes for 1766-67 amounted to Rs. 4,03,334, three annas and one paisa. ${ }^{49}$ Each village paid two kinds of taxes: 'ain and vero ("verraw" in the original). Morley does not explain what 'ain is but we may take it to mean "real" or "true" land revenue, abbreviated from the Persian 'ain jama'

47 The Mir'ät-i Ahmadī, compiled about a decade earlier, says that Bharuch pargana contained 18 o villages as well as a port. Khān, Mir'ät-i Ahmadī: Supplement: 175 .

48 Morley, "Broach Revenues": f. 32. The "undermentioned Moremen" were Hakimjee, Seead Adrooss [Sayyid 'Aydarus], Seead Summy, Codjee Buccaw, Seead Beenaw, Mulasaw Esauch, and Codjee Deewana. From here on, Persian words will be indicated by $(\mathrm{P})$ following the word, Gujarati ones by $(\mathrm{G})$, and Persianate words adapted or transcribed in Gujarati texts by lowercase (p).

Morley, “Broach Revenues”: f. 35. 
or 'ain al-mâl. 'Ain jama' was a commonly-used term used for the statutory, Mughal-Persianate estimate of land revenue ( jama'bandī), or for the gross realized land revenue. ${ }^{50}$ In certain contexts, 'ain jama' could comprise two parts: first, 'ain al-māl or 'ain $m \bar{a} l$, the assessed land revenue, and second, $b \bar{a} q \bar{\imath}(\mathrm{P})$ or khoț vera $(\mathrm{G})$, additional cesses to make up for any losses in preceding years. ${ }^{51}$ In either case, Jamiat Rai's (or Morley's) 'ain seems to represent the traditional share of the produce the sovereign elicited from the subject. In Bharuch, the sovereign was dual: the nawab and the Gaekwad.

Verā ( singular vero) were additional dues, charged by the ruler in addition to the basic land revenue. The common, modern, meaning of vero is simply tax or cess, or, as defined in the mid-2oth-century Gujarati lexicon Bhagvadgōmaṇdal, cash (rokad rakam) charges for government needs levied on farmers over and above land revenue, that could be charged from either individuals or corporate bodies and could include octroi, import and export charges. ${ }^{52}$ The latter is the sense of vero that appears in Jamiat Rai's accounts.

Earlier in the 18th century, however, the word verā carried a connotation of forced taxes. The word first appears with frequency in the 18th century in the Persian accounts of Gujarat, the Mir'àt-i Ahmadī and Mir'àt al-haqā'iq, where it is spelt bivvara, and usually means illegal or extra-legal taxes or fines. ${ }^{53}$ The author of the Mir'āt-i Aḥmadī remarked that he had never heard the term before coming to Gujarat, but that, in his day, this forced tax was imposed by courtiers in Gujarat "on various excuses such as differentiation in trade,

$5^{\circ}$ H.H. Wilson, A Glossary of Judicial and Revenue Terms, and of Useful Words Occurring in Official Documents Relating to the Administration of the Government of British India from the Arabic, Persian, Hindustání, Sanskrit, Hindí, Bengálí, Uriya, Maráțhi, Guzaráthí, Telugu, Karnáta, Tamil, Malayálam, and Other Languages (London: Wm. H. Allen \& Co., 1855): 14. Sharma and Dhot gloss 'ain jama' thus: "Generally speaking the regular or established revenue fixed exclusive of extra cesses, but sometimes applied to the total aggregate sum of revenue including that from land as well as from other cesses." G.D. Sharma and J.K. Dhot, "Marathi Records on the State Revenue in Gujarat During the Second Half of the Eighteenth Century." Indian Historical Records Commission (1985): 97.

$5^{1} \quad$ Sharma and Dhot, "Marathi Records": 97.

52 Bhagvatsiṃjī and C. Pațel, Bhagavadgomaṇdal (Rajkot: Pravīṇ Prakāśan, 20o8), accessed at GujaratiLexicon.com. Verā could also be called zakāt, which, in this case, were not the charitable donations required of Muslims, but road taxes. Wilson lists a number of Gujarati verā and defines vero as "Tax, impost, duty, any tax or cess levied in addition to that on land, as upon trades, professions, goods, and the like: a particular tax levied upon the land, or upon ploughs, in addition to the standard assessment; also a tax levied on the Grasia tenures paying no other revenue to the state." Wilson, A Glossary of Judicial and Revenue Terms: 546 .

53 For details, see S. Sheth, "Business Households, Financial Capital, and Public Authority in India, 1650-1818." Ph.D. dissertation, University of Pennsylvania (2018): 163-4. 
community, head counting, house counting, etc." ${ }^{54}$ From the Mir'at al-haqā'iq, it appears that verā could be imposed not only by rulers but by other powerful individuals as well, such as the banker Khushhal Chand who was instructed to raise a million rupees either through bìvara or from his own firm. ${ }^{55}$ The term also appears in Gujarati records with much the same meaning, such as in a land deed from 1725 that records that Hamid Khan, the deputy governor (näib subadār) of Gujarat, in alliance with the Marathas, had collected three kinds of taxes-khandaṇi (protection money), fourfold jījīo (jizya), and vero-from the 84 castes of Ahmedabad. ${ }^{56}$

As far as I can determine, the terms vero/verā or bīvara do not appear outside Gujarat, nor do they appear before the 18th century. Under the Gujarat sultans (1407-1572) several similar such taxes were charged, for porterage, letter-writing, police dues, on stalls selling various commodities, and so on, but, at least as represented in the mid-18th century Mir'ät-i Aḥmadī, such taxes were listed under the Persian terms hạș̣il (realized revenue) or sā'ir (property tax, customs, or octroi). ${ }^{57}$ In the Mughal system, taxes over and above land revenue were classed as wujūhāt or $b \bar{a} b$ (Persian, plural $a b w \bar{a} b$ ), or, as

54 'Ali Muḥammad Khān and Mịthāāāl Kāyasth, Mir'āt-i Aḥmadī:A Persian History of Gujarat, trans. M.F. Lokhandwala (Baroda: Oriental Institute, 1965): 426.

55 'Itimād 'Alī Khān, Mir'āt al-haqā'iq, f. 342b, cited in Sheth, "Business Households, Financial Capital, and Public Authority in India, 1650-1818”: 189 .

56 Y.I. Dixit, "The Legal Documents (Khatapatras): A Study of the Socio-Economic Life of Ahmedabad Based on Original Gujarati Documents." Journal of the Oriental Institute 38 (1988): 77-8. Khandan̄i is defined as tribute or tax paid to a victorious ruler or overlord. Bhagvatsiṃhjī and Pațel, Bhagavadgomaṇdal. It also appears in Khān and Kāyasth, Mir'ät-i Ahmadì, trans.: 414 and elsewhere.

57 Misra, "Some Aspects of the Economy of the Sultanate of Gujarat": 252-3. The author of the mid-18th-century Mir'ät-i Aḥmadī compiled a list of taxes levied by the later sultans of Gujarat drawn from the account books of a Hindu official who had worked for the sultans' revenue administration, nizāmat. Non-agricultural taxes included the following, many in a characteristic compounds of Persian and Gujarati terms: sā̄ir māndavī (market taxes), dār al-faryād (house of justice?), kotwālì (police tax), dharīcha (not clear: the Gujarati word refers to a widow's second marriage; darīcha in Persian is a small window or goldsmith's mold), nakhās (cattle or slave market), darība-yi läkh (lac stall), darïba-yi tārkash (wire or thread stall), darība afiūn (opium stall), darība ābresham (silk stall), kirāya-yi bārkashi (porterage charges), darība marsalì (correspondence, from murāsala), riyāsat-i muhtasib (the office of the censor and inspector of weights and measures), kirāya-i dukākin (rent on shops), hạșil darwāza-yi pūrchāt (revenue from the gates of suburbs (from Gujarati pura or pol?)), ḥạșil darwāzahā-yi shahr (revenues from city gates), pūrchāt (suburbs), hạșil mutthī wa chūngì (taxes on grain sellers, referring to a fistful of grain), and so on (vaghaira kirāya). See 'Alī Muḥammad Khān and Mīṭhālāl Kāyasth, Mir'āt-i Aḥmadī, vol. 1 (Baroda: Oriental Institute, 1926-30): 17-8. The translations are amended from those in Khān and Kāyasth, Mirāt-i Aḥmadī, trans.: 13-4. 
in an explainer (sharh) pertaining to Aurangzeb's farmān of 1666, hạașil and muhtarifa. There were two forms of jihāt, one set (māl-o-jihāt) closely tied to land revenue and intended for the payment of revenue officials, and the second, sä̈ir-jihāt, including taxes on markets, occupations, octroi, and so on. ${ }^{58}$ Both sets were included in the jama', the assessed revenue. Additional cesses levied by officials or local landholders that did not appear in the jama' included farū'àt or farü'iya ăt. ${ }^{59}$ The term bāb was used for non-agricultural taxes in the Hindu kingdom of 17 th-18th-century Marwad, as in other parts of north India. ${ }^{60}$ In eastern Rajasthan, sāir jihāt was the term commonly used. In the Maratha territories, verā-like additional taxes were collectively called, from Persian, siwāy (or sawai) jama'. Meanwhile the 'ain al-māl or jama'bandī, the assessed revenue, remained constant, and the siwāy jama could change based on the ruler's needs. ${ }^{61}$

There are two possibilities for the origin of the word vero/verā. The first is that it is an indigenous Gujarati word linked to Sanskrit vyavahāra (transaction, business, trade), Sanskrit/Prakrit dvāra (door, gate), Gujarati vepār (trade), or $v e v \bar{a} r$ (dealings). ${ }^{62}$ If the term is an indigenous one, it does not appear in early sources. In the predominantly Sanskrit vocabulary of the Caulukyas of Gujarat are several non-agricultural taxes that were functionally similar to verā but none that sound similar. ${ }^{63} \mathrm{~A}$ second possibility is that it is a vernacularization of farū'iyāt, a Persian term used in 17th-century Gujarat for "forbidden taxes." ${ }^{4}$

$5^{8}$ Habib, The Agrarian System of Mughal India: 283-4, citing Abu'l Fazl, A'ten-i Akbarī, trans. H.S. Jarrett, vol. 1 (Calcutta: Asiatic Society of Bengal): 94, 300-1.

59 Habib, The Agrarian System of Mughal India: 284, n. 5. Habib cites A'̄én, vol. 1: 294 and a proclamation of the faujdar of Sorath, in Gujarat, referring to "the forbidden abwāb (taxes), such as farüiyāt." Other terms for such additional taxes included ikhrājāt and hubūbāt.

6o Cherian, "Ordering Subjects": 286-91.

61 Sharma and Dhot, "Marathi Records": 85.

62 M.B. Belsare, An Etymological Gujarati English Dictionary (New Delhi: Asian Educational Services, 1993): 1071.

63 For example, an increase in rent, malärgaṇa (c.f. Gujarati malavero), levied to raise funds for a dignitary, or taxes collected for festivities or to maintain police facilities. A.K. Majumdar, The Chaulukyas of Gujarat (Bombay: Bharatiya Vidya Bhavan, 1956): 242. See also Surabhi Srivastava, "Fiscal Terms in Western Chaulukya Testimony." Proceedings of the Indian History Congress 74 (2014): 1387.

64 See note 6o above. Also see E. Lhost, "Writing Law at the Edge of Empire: Evidence from the Qazis of Bharuch (1799-1864).” Itinerario 42/2 (2018): 263. In a Persian manual for jurists produced in Bharuch in the late 18th century, Lhost notices the choice to spell the Arabic term färigh-khațtì (deed of release) as pāra-khațți, reflecting Gujarati orthography that conflates the aspirated $p h a$ and the fricative $f a$. Here again, contemporary Gujarati usage was inserted instead of normative Arabic spelling. 
If the latter, it is interesting that later Persian writers such as 'Ali Muhammad Khan, Mithalal Kayasth, and I'timad Khan "Persify" the Gujarati word vero as bivvara instead of using the Persian farūiiyāt, a proceeding that suggests vero was an accepted part of Gujarati tax lingo for 18th-century writers.

Jamiat Rai's record for $1766-67$ listed no less than 34 kinds of verā, dues levied by the nawab in addition to the 'ain taxes. The proceeds of each were divided between the nawab and the Gaekwads. While the 'ain taxes were always higher than the verā, the latter represented a substantial additional amount from each village, occasionally even up to $95 \%$ of the 'ain. ${ }^{65}$ Morley's list, followed by his helpful glossary, contains 34 kinds of vero of which I can reliably translate 27 (See Appendix 1 for a full translation). Of these, 16 terms include Persianate words, often in compounds with Gujarati terms for taxes, such as: Cummy verraw ( $\operatorname{kami}$ (ك) vero), levied to make up for a shortfall in revenue the previous year, or Ruzzah bhet (raża a (رضاء) bhet.), paid by farmers for permission to harvest their crops. Other terms are entirely Persianate: Durbar curch (darbār kharch دربار خزت), for court expenses, or Vizzeat (ważآَat وضيعة), for durbar servants. Certain taxes with Persianate names were derived from the titles of office-bearers: Karkoon putty from kārkun (كارك), scribe or clerk, was levied by the desāi to pay for presents; Havaldaree (hawāldārī, from حوالدارى) was levied to pay sentries to protect the crop; Jaudar soocry (jama'dār sukhdī) was an amount originally levied to pay the jama'dār (جمعار) or troop commander, later largely usurped by the nawab; and Naibut jaudarsoocry (naibat jama'dār sukhdī) was to raise payment for the jamadar's deputies. Vizzefdar (وط:zizifa-dār was listed to record that the Muslim holders of rentfree wazîfa lands paid taxes to the Gaekwads although not to the nawab. Fozedaree (faujdārī) stood for fines for misdemeanors, and Motesabby

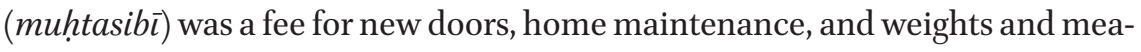
sures. Once again, the terms for taxes in these compound terms-vero, patți, sukhdil, and bhet. - were all Gujarati, except for the Persianate kharch. Sukhḍi is a Gujarati term for a bonus or gift to officials or brahmins. Patți is an old word for tax, sometimes used for the amount raised to honor a social superior. ${ }^{66}$ Similarly, bheț was used for gifts.

A few terms were derived from Persian words in common use: Pawlez, or $p \bar{a} l e z$, from the Persian for kitchen-garden or melon-field, was a tax imposed on market-gardeners, Phoorza ( furza) represented customs dues, and Nimmak

65 This corresponds with Guha's observation, based on Maratha sources, that "half the gross "rent"' in late Mughal India came from commercial exactions, bribes and gifts. Guha, "Rethinking the Mughal Economy": 566-7.

66 Bhagvatsiṃjī and Pațel, Bhagavadgomaṇdal (GujaratiLexicon.com). 
Saw (namaksār, نكار) was raised by farming out the right to make salt near the mouth of the river. The remaining terms are in Gujarati. Gollaw verraw or gola $\bar{a}$ vero was a tax to raise funds for gunpowder or shot, "Dhawnaw" or dhāno $(\mathrm{G})$ was probably intended to pay for grain for horses, and Dawroo Butte (dārū bhatțhì) was a tax derived from farming the right to make the alcoholic brew arrack.

The Gaekwads received a 6०\% share on six of the line items above. "Cump Verraw," "Dhawnaw," "Pandria Saunder," "Menaw Ghiry," and "Vizzefdar" were levied only by the Gaekwads. Most others were shared equally with the nawab. "Key verraw", described as "A Tax which was first levied about 20 years ago and has ever since been continued to reimburse the Govt for the Expenses of Digging a Ditch around a small fort at a Village called Soryare" was also levied, in that year, only by the Gaekwads. A number of verā were designed to pay for gifts or gratuities to officials. There was a tax levied on a festival ("Dusraputty" or Dasera tax "defraying the Charge of presents which the Nabob made on the Occasion to the head Jumadar, Patells and principal People of the Town." 67 The kārkun patțī used formerly to be levied by the desāi "to pay for Presents he gave annually to the principal people of Government to engage their Interest in his Favour," but in late years the amount had gone to the nawab. ${ }^{68}$

In some cases it is clear who the taxpayers were. It is noteworthy that many of the levies were imposed on relatively low-status professionals such as fruit and vegetable growers, shopkeepers, and goatherds whereas high-status individuals enjoyed tax remissions in the shape of in'ām or wazīfa grants. ${ }^{69}$ Farmers had to pay for permission to reap their grain in the harvest season, and homeowners paid for the privilege of cutting wood and fixing doors in new homes. Arrack and salt production were farmed to the highest bidders who paid taxes for the privilege. The modi or chief grocer collected 18 rupees a month from the shopkeepers, handing over 12 to the nawab and keeping the rest. In other cases,

67 Morley, "Broach Revenues": f. 36.

68 In some cases, perquisites charged by village officials in Gujarat were paid by villagers and then deducted from the revenue demand. Khān and Kāyasth, Mir'ät-i Aḥmadī, vol. 1: 2756, in Habib, The Agrarian System of Mughal India: 287, n. 32. The Mughals made repeated attempts to curb additional extra-legal charges- "customary or compulsory gifts like salāmī and bhenț; fines and bribes, collectively called bälädastī (high-handed"); payments expected on the performance of certain definite acts by the officials, e.g. pattuad $\bar{a} r \bar{r}$, on the grant of a patța, balkațī, when permitting the crop to be cut, and tahṣilldārī, when presumably accepting the payment of revenue; and, finally, kharj-i șādir o wārid, "expenses on those coming and going to meet the needs of the officials during their visits." Habib, The Agrarian System of Mughal India: 288.

69 S. Guha, "The Politics of Identity and Enumeration in India c. 1600-199o." Comparative Studies in Society and History 45/1 (2003): 153. 
it is not entirely clear who paid certain dues. Taxes were levied (from farmers? townspeople?) for particular government needs, for example the purchase of ammunition, hay, thread, leather, and grain..$^{70}$ Although the ghāmsì vero was a tax to pay for hay, in recent years the villages had supplied the nawab with free hay for his horses in addition to paying the tax. Certain one-time expenses turned into annual taxes: a levy to pay for digging a ditch around a small fort, levied twenty years prior, had become a regular fee, as had the soni vero (levied on goldsmiths or gold transactions?), previously levied to help the government in the case of an emergency.

There is no line item for paying regular soldiers in this table. In other words, the basic requirements of military fiscalism must have been borne by the nawab from his regular ('ain) share of the revenues. The verā paid for additional court and military costs: durbar expenses, for soldiers to be sent "on any Extraordinary Business," and for policemen (one each to represent the nawab and the Gaekwads) to catch tax defaulters. Of course some of the verā no longer went to their original intended recipients; for example, the jama'dār sukhḍi and naibat jama'dār sukhḍi originally levied to benefit the military commander and his deputies had in recent years been largely appropriated by the nawab.

Some taxes were devices to keep the wheels of government running. There was a tax to make up for any deficiency in the taxes collected the previous year. There was a tax levied against the possibility that taxes might be paid in "bad money." Taxes on the mint varied with the amount of coinage minted annually. There was even an amount, between three and five hundred rupees annually, which the nawab received from the cotton merchants, "the Intention of which was to prevent his taking notice of their mixing seed in the Cotton." ${ }^{71}$ Finally, if the nawab and the Gaekwads needed to make presents to each other, additional verā would be levied.

If we are to treat Morley's notes as accurate, we have a fascinating picture of the nawab's sources of revenue. He received a "regular" or 'ain taxed amount from each village which was based on the jama', the pre-assessed estimate of revenue. In addition, he received the verā amounts, which were generally less than the 'ain amount. Sixty percent of the 'ain amount and some of the verā were shared with the Gaekwads - which suggests the verā had been common since the revenue-sharing agreement was made in 1740. Clearly, the 'ain

$70 \quad$ This may originally have been a "voluntary" offering of grass, grain, thread, or similar items by villagers. Over time it turned into a cash amount pegged to the price of the commodity. See discussion of a similar ghee vero in my article "Jibhabhu's Rights to Ghee": 368-70. 
amounts were insufficient to run the government and to pay its employees and representatives. The verā filled in the gaps. If the nawab needed extra money, he would not increase the 'ain amounts, which were pre-assessed and collected in the old Mughal way. He could simply add verā, as he did in 1772 when he was trying to raise money to pay the British for customs dues they insisted were owed to them:

And after a few days he explained the amounts [raqam-i ma'mulāt] on which they had agreed, and asked his relatives and subjects in the city for help. He divided the amount into four parts: one share which he would undertake, the second to be borne by his relatives, the third by the Muslims of the city and the fourth by the Hindus. Thereupon, a huge turmoil rose and the people of the city started to curse [bad-du'a]... A command was issued to the administrators to collect a bīvara [verā] of gold, so that over three months through a thousand kinds of hardships and tortures and punishments, one assigned share amounting to 35,000 rupees, was collected. ${ }^{72}$

It is worth considering whether the nawabs deliberately under-assessed the 'ain. This suspicion is borne out in a letter extolling Nawab Mu'azzaz Khan's policy of keeping land assessments low to enable cultivators to pay their assessed taxes. ${ }^{73}$ Such a dodge would appear as a gesture of benevolence towards his subjects but it could have two additional functions: to reduce the amount the nawabs were obliged to pay to the Gaekwads (and, previously, to the imperial treasury), and perhaps also to allow for the proliferation of verā.

In the absence of imperial regulation, there was little check on verā. The nawab could — and did —impose additional burdensome verā when he needed the money. Officials, such as the desāī, were authorized to impose verā, just as the banker Khushhal Chand was so authorized in 1725. The exaction of extralegal taxes, whether by state bureaucrats, bankers, revenue officials, or little princes such as the nawabs of Bharuch, was a common practice in late-Mughal South Asia, and was constrained only by the fear-or threat—of reducing future trade and productivity. ${ }^{74}$ Describing a similar situation in 17 th-century Marwar, Divya Cherian remarks that only "custom" and resistance from taxpayers could limit such taxation. ${ }^{75}$ In the 18th century, the levying of ever more

\footnotetext{
72 Haqüqat-i Bandar Bharūch. Bodleian Library, Oxford, Ms. 2474: ff. 32b-33a.

73 Ahmad, History of the Nawābs of Broach: 142, letter 16/3.

74 Guha, "Rethinking the Economy": 569.

75 Cherian, "Ordering Subjects": 297.
} 
extortionate verā was a feature of a time when fiscally-challenged new contenders for power, including Mughal-appointed but increasingly autonomous officials, engaged in entrepreneurial revenue gathering. ${ }^{76}$

The distribution of Persian and Gujarati vocabulary in Morley's tables may be read as an index of the relationship between the imperial and the local. The Mughal (Persian) revenue arrangements represented by the 'ain jama' continued to be the indispensable scaffolding for revenue extraction but were inflexible and unsuited for entrepreneurial politics. It was the additional verā, acknowledged as common - if reviled—-local practice since the 16th century, that facilitated the networks of hierarchy and obligation that kept the empire going and expanded to fuel the new entrepreneurial politics. The two systems were intertwined. Mughal-granted authority to collect the 'ain conferred on an aspirant the authority to additionally solicit verā, which is why 18th-century political entrepreneurs continued to seek charters from the hollowed-out Mughal crown. The relationship between the static 'ain and the burgeoning verā in the 18th century was, on the one hand, a symptom of the increasing disarticulation of the imperial and the local. On the other hand, it was an indication that verā were intrinsic to the Mughal system, part of a longer history in which revenue intermediaries exercised functional and linguistic autonomy, using a scaffolding of the mandated Persian terminology while continuing to foster the hierarchical, tributary, and affective relationships suggested by the Gujarati terms. The Persian-Gujarati compound phrases demonstrate these relationships, with Persian terms generally used for offices (jamaddār, kārkun) and Gujarati terms for entitlements (verā, sukhḍī, patțī). However, Persian revenue terminology was not imposed on the vernacular Indic world through conquest, as nationalist historiography would have it. The 'ain (Persian) and vera (vernacular) constituted each other in a distinctively Mughal system.

Further, in Gujarat, there was one significant difference from elsewhere in the empire. Unlike Hindu kingdoms such as the Marathas and various Rajput states that adopted the Mughal Persian terminology for non-agrarian taxes (bāb, sāiir jihāt, sivāy jama'), the term used in the directly-ruled parts of Mughal Gujarat was the vernacular vero. Even if it was a vernacularization of the Persian farū'iyāt, it was understood by contemporary Persian writers as a Gujarati usage. Correspondingly, whether Jamiat Rai's accounts were

$7^{6}$ Sudev Sheth astutely remarks that the appearance of vero as a term for illegal taxation suggests that "local life in Ahmedabad was coming to be dictated by political lexicons adopted and reframed by recalcitrant governors within the established but decaying apparatus of the Mughal state." Sheth, "Business Households, Financial Capital, and Public Authority in India, 1650-1818”: 163 . 
in Gujarati or Persian, in a commercial script, Nagari, or Perso-Arabic, or a mixture, the Persianate vocabulary of Mughal power was uniquely woven through with the Gujarati vocabulary of indigenous capital (vyavahāra, vepār, vero, bīvara).

Almost half a century later, much had changed in Bharuch. In 1782, the British had been forced to give up the district to the Marathas who displayed little respect for the entrenched land-revenue firms and forced them to bid to farm Bharuch's revenues. Lallubhai, who fell into debt trying to raise money for his bid, was thrown into prison and died in $1800 .{ }^{77}$ The British regained Bharuch in 1803 as part of the settlements in the wake of the Anglo-Maratha wars and soon turned their attention to its revenues again. By this time, Jamiat Rai was dead and his and Lallubhai's successors had considerably less influence in Bharuch. ${ }^{78}$ Meanwhile, the bottom was dropping out of the market for cotton fabrics and the local weaving industry was disintegrating. In 1825, Monier Williams, collector of Bharuch in the 1820s, wrote that as high-quality English cloth could be purchased at "about half the price of the dotees and baftas, even on the spot where they are made, this manufacture is of course going rapidly to decay." ${ }^{79}$ With the hereditary district officers out of the way, and the district only of value for its raw cotton and land revenues, Bharuch became a test location for experiments in revenue surveying. ${ }^{80}$

Illustrating British officials' attempts to systematize revenue record-keeping is a "field book" or jarîf-no chopdo containing the assessment and revenue records of the village of Kajipura in the pargana of Matar, Bharuch district, from 1820 , at which time the British had been re-established in Bharuch for seventeen years. From the collections in the Bodleian Library of the Sanskritist

77 Revenue arrangements in Bharuch during the Maratha interregnum are explored in a chapter of my forthcoming book.

78 W.G. Pedder, Papers Relating to the Settlement of the Hereditary District Officers' Watans in the Deccan and Gujarat (Bombay: Government Central Press, 1895): Appendix C, "Sketch of the History of the Broach Watans, especially with reference to the families of Dowlutrai Desài and Lallubhai Majmudár": $343-52$. On Lallubhai's successor, his widow Jibhabhu, see Sheikh, "Jibhabhu's Rights to Ghee."

79 M. Williams, Memoir on the Zilla of Baroche; Being the Result of a Revenue, Statistical, and Topographical Survey of That Collectorate; Executed by Order of the Bombay Government (London: Cox and Baylis, 1825): 121.

8o See N. Rabitoy, "System v. Expediency: The Reality of Land Revenue Administration in the Bombay Presidency, 1812-1820," Modern Asian Studies 9/4 (1975): 529-46. 
Sir Monier Monier-Williams, presumably inherited from his father, the erstwhile collector of Bharuch, the field book is a rare surviving example of a village-level revenue survey of the early colonial period. ${ }^{81}$

The field book demonstrates continuity as well as change in land-revenue practices since the 1770s. It is in Gujarati with copious interlinear annotations in English, either by the senior Monier Williams or by the superintendent of the revenue survey, Lieutenant Ovans, who declared the document to be "Original." 82 (For translation, see Appendix 2.) The book sprawls over 46 foolscap-like folios, drawn up with space for extensive annotation. The numerical calculations are simple and neatly compiled.Jarif-no chopdo, as the book identifies itself on the first complete page, is a Persian-Gujarati composite term comprising jarif from Persian jarīb, a unit of land or area, and chopḍo, Gujarati for book. The terms suggest that the language of Persianate/Mughal-style revenue assessment still prevailed in the 1820 s, but, as we shall see, the British had now put in place changes that included English interpolations and vernacular elaborations.

The annotator tells us in English that two copies were always made of the field book. The calculations in the second copy were made by a second person and were entered and added up in reverse to ensure the veracity of the original. The corresponding Gujarati text has more details, explaining that the measurements and figures of the jariff (here abbreviated from jarïb-amin, or surveyor) were on top and those of the talāțī, village accountant, were below. The manuscript begins with a section on the measurements employed: the basic measure was of a bamboo rod, exactly 5 "hands" or 8 English feet long. The units of measurement were gaj and lìg. 25 līg made up one vasvāmsīi, 500

81 Shah et al., "Early Nineteenth Century Village Records in Gujarat": 128, 130. In the 1950s, when A.M. Shah and colleagues studied early 19th-century revenue records in neighboring Kheda district, they found references to survey books or land registers (called taläți-na namūna in Kheda) but were unable to find any of the original books or registers.

82 The annotator goes on to note, "Of this Book a duplicate is always formed in which all the calculations are made by a separate person, at a different time and by reversing the figures. This is done to verify the original. It is afterwards left at the village for the use of the people. The memorandum of the village Dara, or mode of collecting the government revenue - the Juma Khurch or account of village Receipts \& disbursements \& the Statement of the population are therefore not inserted in the duplicate." Jarif-no chopdo (Measurement Papers and Records of the Village of Kājipurā, Parganah Mātar, in the Broach District of Bombay), Bodleian Library, Oxford, Ms. Ind.Inst.Misc.17: f. 4. The compiler, Lieutenant C. Ovans, later became political agent at Satara, where his involvement in the deposition of the ruler Pratap Singh caused him (Ovans) to be accused of corruption and impeached. See Debates at the India House: August 22nd, 23rd and September 14th, 1845, on the Case of the Deposed Raja of Sattara and the Impeachment of Col. C. Ovans (London: Effingham Wilson, 1845). 
made one vaso, and 10,0oo made one vighu (bïghā). Apart from "līg," these are all Mughal measurements found in the A'în-i Akbarī. ${ }^{83}$

The next page explains what the book is: a book of the measurements of the fields produced under the superintendence of Lt. Ovans. The fields were measured by officials from neighboring villages: the amin patel İsapjī Miānjī of village Khojbal and the aminn Mugațrām Harirām of village Dora. The Arabic-Persian term amīn refers to a village-level official appointed to measure lands; amin patel was a village or community headman who held the title of amin. ${ }^{84}$ The measurement was carried out in the presence of representatives of the village farmers: one member each from the Kalmi Leva and Koli Talabda communities, two from the Koli Patanvadia community, and the talātị or village accountant, an Audich brahmin named Harīnāran Govandrām. It is worth noticing that the farmers are classified by $j \bar{a} t i$, endogamous group, with all belonging to middling- or lower-status groups. While the talātị’s brahmin status is identified, the amins' community affiliations are not provided, although one may surmise that İsapjī Miānjī was a Muslim and Mugațrām Harirām a Vaishnava.

The book continues with 33 pages of measurements of the holdings of individual farmers with details of their dimensions, the kind of soil, the crops being produced (including trees, such as mango or the alcohol-producing mahudo), and the assessed revenue. Duly recorded is the name of the landlord, the tiller of the soil (in a few instances they are the same), and whether any of the land is disputed. At the end is a calculation of the total area under cultivation in Kajipura village, including all cultivable land, wasteland, villages, ponds, and so on.

Next follow memoranda (Gujarati īädās, Persian yāddāsht) of different aspects of revenue assessment and collection in the village. One demonstrates incentives offered for the bringing marginal, marshy lands under rice cultivation. The tax was assessed per bīghā of land and varied based on the crop being grown and the quality of the soil. If fallow or uncultivated land was turned into

83 A thorough discussion of the evolution of the standard Mughal unit of land measurement, gaz (gaj in Gujarati), is to be found in Habib, The Agrarian System of Mughal India: 406-15. Measurement with a bamboo rod, țanāb-i bāns, was introduced in 1574-75. Abu'l Fazl, the author of the A'în-i Akbari, explains that a bigha was the square of 60 gaz, a 20 th part of a bīgha was a biswa, and a 2oth part of a biswa was a biswānsa. Abu'l Fazl, Á'̄n-i Akbarī, trans. H.S. Jarrett, vol. 2 (Calcutta: Asiatic Society of Bengal, 1891): 62. Biswa is thus equivalent to Gujarati vaso and biswānsā to Gujarati vasvāṃsī. The only term not

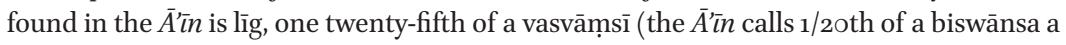
taswānsa).

84 Bhagvatsiṃjī and Pațel, Bhagavadgomaṇdal (GujaratiLexicon.com). 
rice-growing land, the vighoțī, or tax assessment per bīghā, could be frozen for a period of five years. Marginal lands taken into cultivation would pay lower annual rates, rising gradually (one rupee per bighā for the first year and $1 \frac{1 / 4}{\text { the }}$ following year).

Another memorandum is on the payment of salämi-a Persian term for tribute- to the government on lands either mortgaged (ghareniu) or alienated as tax-free gifts (pasāitu). It is noteworthy that the government continued to receive a small income even on alienated lands. Another memo explained that of the rice produced in the village, half was the cultivator's while the other half went to the government, with Rs. 3 deducted from the cultivator's share to pay village servants. Of the second crop of the year, usually barley, wheat or chino (sugarcane?), three-fourths went to the cultivator without any deduction. There are memos on pasāita and chākariā lands granted to village servants in lieu of services and — as before! — additional verā demanded by the government. ${ }^{85}$ For every plough pulled by two bullocks, the farmer paid two rupees, and for a one-bullock plough, a rupee. If these charges were paid, the village would be freed from paying further charges for cowdung cakes, firewood and grass.

One schedule deals with the jama'-kharch (receipts and disbursements) of the village in the year 1819, with disbursements including payments to the accountant for paper and salaries. At the end is a ìädās färagatīnì, memorandum of release, from the Persian yāddāsht (memorandum) and färigh-khaț̣i (deed of release), a declaration signed by the village pațel and talāțī, promising that they had paid for the village measurements and that no monies had changed hands other than those authorized by the government.

A key feature of the field book was a village census or kul-vastī, a PersianGujarati compound meaning total habitation. The census has ten columns. The first column contains a list of household heads organized by jāti, or endogamous "caste." The village contained members of four jātis: Kalmi Leva (3 households), Koli Talabda (6 households), Koli Patanvadia ( 36 households), and one household of Vasvayas. The remaining 9 columns listed the number of homes, men and boys, women and girls, total number of humans (153), oxen and male calves, cows and female calves, buffaloes and calves, carts, and ploughs belonging to each household. ${ }^{86}$ One woman of the Koli Patanvadia

85 Jarîf-no chopdo: f. 42.

86 The terminology used in this census corresponds almost exactly with what A.M. Shah and his colleagues found in a comparable census of Kheda district from 1817, which would suggest concerted enumerative action at least in south Gujarat. Shah says no such detailed census was carried out after 1826. (The India-wide decennial census introduced 
jāti named Pardesan Rupa lived alone with her bullock; all the other households were headed by men. In its form-a jāti-wise enumeration of persons and animals - the census bears a closer resemblance to precolonial household registers like Munhata Nainsi's lists from Marvad in the late 17th century than to the colonial census that began in $1871 .{ }^{87}$

In the absence of a corresponding field book from an earlier period, such as one that might have been kept by Jamiat Rai, it is possible in this document to discern changes from precolonial practice as well as significant elements of continuity. The first change is the very availability of the field book as well as its legibility in Nagari-script Gujarati with English annotations. The second change is from the pargana to the village as the key unit of revenue management. Correspondingly, the crucial official is now the talāțī or salaried village accountant rather than the entrepreneurial desāī or majmū'dār. The talāṭi was the author of the field book which was to be delivered directly to government, in the shape of Lt. Ovans, without any intermediary. There was now a direct and unmediated flow of information from village to government.

What persists is threefold. First, there is a continuity in the notion of superordinate government, sarkār, that is conceptually undifferentiated from the 'ain- and verā- extracting government of Jamiat Rai's records. ${ }^{88}$ In spite of the fact that two embodiments of prior government- the nawabs as well as the desāis and majmū'dārs — had by now been dislodged, the British had merely replaced their predecessors as sarkār. As before, officials were appointed by the sarkār, fields measured for the sarkār, and taxes or crop shares paid to the sarkār. The field book recognizes that the sarkār's personnel were British (sāheb) but otherwise makes no distinction between any prior government and the current one.

in 1871 did not go into such granular detail of households and livestock.) Shah et al., "Early Nineteenth Century Village Records in Gujarat": 131.

87 For Nainsi's census see N. Peabody, "Cents, Sense, Census: Human Inventories in Late Precolonial and Early Colonial India." Comparative Studies in Society and History 43/4 (2001): 824-829. Peabody and Sumit Guha reject the notion that the post-1868 colonial census was an administrative novelty and demonstrate how precolonial regimes counted and calibrated communities and households. See also Guha, "The Politics of Identity and Enumeration."

88 For the etymologies and uses of the word sarkār and its transition from a descriptor of interlocked patrimonial relationships to territorially-bounded states, see N.J. Abbott, "Bringing the Sarkār Back In: Translating Patrimonialism and the State in Early Modern and Early Colonial India." In State Formations: Global Histories and Cultures of Statehood, ed. J.L. Brooke, J.C. Strauss and G. Anderson (Cambridge, Cambridge University Press): 124-137. 
Second is a durability in the categories of information sought and in the methods of collecting it. The bulk of the document consists of measurements of holdings, documentation of land ownership, and assessments of crops and yields. The kul-vasti is organized on precolonial lines and, as in the rest of the document, records fiscal and hierarchical information that was equally critical to the organization of the precolonial and colonial state. Just as in Jamiat Rai's accounts, we see close attention paid to taxes and tax-free grants of land.

Finally, there is a continuity in the transregional Mughal and Persianate revenue terminology (e.g., bīghā, bīsvā) that suffused a text written in Gujarati for British administrators. The terms for length and area correspond, with the exception of the words lig and feet, to Mughal equivalents. Dates are according to the Gregorian as well as Vikram Samvat calendars. The field book contains characteristic Gujarati usages such as vero, as discussed above, ghareṇiu for mortgaged land, and pasāitu, tax-free land for village servants, all of which terms appear in earlier records, and there are in addition a number of Persian-Gujarati compound terms. During almost a half century of transition from early Company rule in 1772 to unquestioned control in 1820 , Persianate Gujarati and its association with government proved to be resistant to regime changes. Even if the colonial state's village-level documentation was exclusively in Gujarati and according to a set template of required information, Gujarati now had a baked-in Persianate vocabulary. While the whole stratum of revenue personnel was now replaced by salaried village accountants, prevalent technical terms and units-and corresponding conceptual categories-were harder to dislodge.

\section{Conclusion}

With important exceptions, a significant part of theorizing on precolonial land revenue has been based on normative or prescriptive texts. ${ }^{89}$ There are several reasons why historians have relied primarily on such sources. The first is that prescriptive texts offer a tidy picture of land relations and suggest a well-functioning, centrally-controlled imperial machinery, a picture of Mughal order and intent that appealed to the anti-colonial impulses of postcolonial historians. For instance, the A'in-i Akbarì offers a reassuring image of imperial benevolence when it came to customary taxes over and above land revenue. Deeming such charges to be "troublesome and vexatious to the people," the

89 For a thorough critique of historians' credulity with respect to Mughal imperial data, see S. Guha, "Rethinking the Economy of Mughal India": 532-3 and passim. 
emperor Akbar had "in his wise statesmanship and benevolence of rule carefully examined the subject and abolished all arbitrary taxation, disapproving that these oppressions should become established by custom." ${ }^{90}$ Another reason is that texts of practice are hard to come by, probably by design, because they formed a critical part of the knowledge capital of land revenue family firms such as those of Jamiat Rai and Lallubhai. Even when found, they are not easy to interpret (a feature that led British officials to cast them as illegible or disorganized) and offer a messier picture of land relations that can be at odds with the orderly vision of the prescriptive texts. While more records will undoubtedly come to light, the problem of apparent scarcity of sources might also be addressed by regarding archives as activities, or as sets of "cultural and social practices" rather than as spatially-defined repositories. ${ }^{91}$

Further, texts of practice are often sidelined as evidence of localized or deviant conventions rather than as manifestations of how the system worked because they reveal that the system was, in spite of Akbar's stated benevolence, always extractive and entrepreneurial, only constrained on the one hand by a thin layer of often unenforceable imperially-mandated norms and on the other, by the exigencies of local politics and customs. As more land revenue texts maintained by family firms come to light, and as our attention turns to a wider range of documents and documentary traces, the better we will be able to explicate the "social logic" of paper cultures. ${ }^{92}$ I expect further research will continue to destabilize normative pictures of state activity and demonstrate a lively stratum of district-level expertise and entrepreneurship that functioned within the broad framework of Mughal Persianate law but with only sporadic oversight by the higher reaches of the Mughal bureaucracy.

Their early experiences with the likes of Jamiat Rai and Lallubhai set the British against the entrepreneurial family firms, now cast not only as "troublesome or vexatious," as they were by Akbar, but as ignorant and inscrutable interlopers who obscured the proper functioning of government. As the British listed all prevailing taxes and measured the land, placing the elicited information in Gujarati-language docketed archives, they succeeded in cutting into the complex, multilingual webs of knowledge and authority wielded by the

\footnotetext{
9o Abu'l Fazl, A'īn-i Akbarī, trans. Jarrett: vol. 2: 58 .

91 Hirschler, "From Archive to Archival Practices": 2.

92 Ibid.: 27. For important interventions on paper cultures in South Asia see B. Raman, Document Raj: Writing and Scribes in Early Colonial South India (Chicago: University of Chicago Press, 2012), H.J. Bellenoit, The Formation of the Colonial State in India: Scribes, Paper and Taxes, 1760-186o (London and New York: Taylor \& Francis, 2017), and Chatterjee, Negotiating Mughal Law.
} 
family firms in a way that had been impossible for the Mughals. ${ }^{93}$ By edging out such "privatized" desāī and majmū'dār firms, and replacing them with subservient village talāțis, the early colonial state rooted out revenue entrepreneurship and staked control over the invaluable commodity of the revenue archive. Revenue records, safely and legibly organized in record rooms, were deemed to have been rescued from the domain of entrepreneurial commerce and restored to the domain of the law and the state. By claiming direct access to revenue records to establish an imperial system of rights and privileges, it might be argued that Company officials were not putting in place a nascent British empire. Rather, they were restoring the benevolent Mughal imperium as imagined in Persian by Abu'l Fazl. ${ }^{94}$

What exactly changed between the late-Mughal/early colonial period and the 1820s? First, as we have seen, emboldened by their victories in the Anglo-Maratha wars, the British pensioned off or dismissed the long-established, patrimonial, semi-autonomous district (pargana) officials on whom they had relied in the early days, appointing in their stead salaried village officials overseen by British revenue collectors. Such officials had already been weakened by the Maratha interregnum (1783-1803), when they were forced to bid for the farm of the district's revenues. Second, they succeeded in mandating the replacement of the contextual multilingualism of revenue practice, operated in south Gujarat by district officials and comprising written and oral versions of Gujarati, Persian, Hindi, Marathi, and English, by written Gujarati in Nagari script, overseen by English. Multilingualism and opacity allowed its practitioners to withhold information and resources from the state; Gujarati-English bilingualism and standardization facilitated transparency. In theory, at least, the board of governors of the EIC could examine and weigh in on revenue collection in Bharuch in a way the Mughals had never achieved. Third, the emphasis in record-keeping shifted from the relational language of hierarchy and obligation, as witnessed in the plethora of customary dues, to the dawning of Cohn's survey and enumerative modalities. ${ }^{95}$ No longer could village patels

93 Cohn's "enumerative modality" for the "creation of social categories by which India was ordered for administrative purposes" is relevant here, although taking place earlier than in Cohn's examples. B.S. Cohn, Colonialism and Its Forms of Knowledge: The British in India (Princeton: Princeton University Press, 1996): 8. See Guha, "The Politics of Identity and Enumeration" for a fruitful critique of Cohn and his successors.

94 For an argument that the early colonial impulse to restore an ancient Mughal constitution to Bengal waned in the 178 os and 179os, see R. Travers, Ideology and Empire in Eighteenth-Century India: The British in Bengal (Cambridge: Cambridge University Press, 2007), especially chapter 6.

95 Cohn, Colonialism and Its Forms of Knowledge: 8. 
register political discontent by failing to proffer a sukhḍi or claim protection in return for a whip-round vero. The new imperial system was equally extractive and perhaps even more violent but was impersonal by design.

Ultimately it doesn't really matter what language Jamiat Rai scribbled in; what matters is that multilingualism and entrepreneurship in land revenue administration was too unruly, opaque, and reliant on affective relationships for the increasingly profit-driven new administration. By forcing in place a new subservient Gujarati monolingualism, the British had succeeded, by the 1820s, in siphoning up the flow of information and resources in a way the Mughals had desired but never realized. This was not the end of the story, of course, but the consequences of the new system in the later 19th century, including the recurrence of patrimonial authority within the colonial system, the rise of modern Gujarati, and the emergence of new forms of peasant protest, are beyond the scope of this paper. 
Appendix 1: Particulars of the foregoing Verrow together with Sundry Articles of the Town Revenues ${ }^{96}$

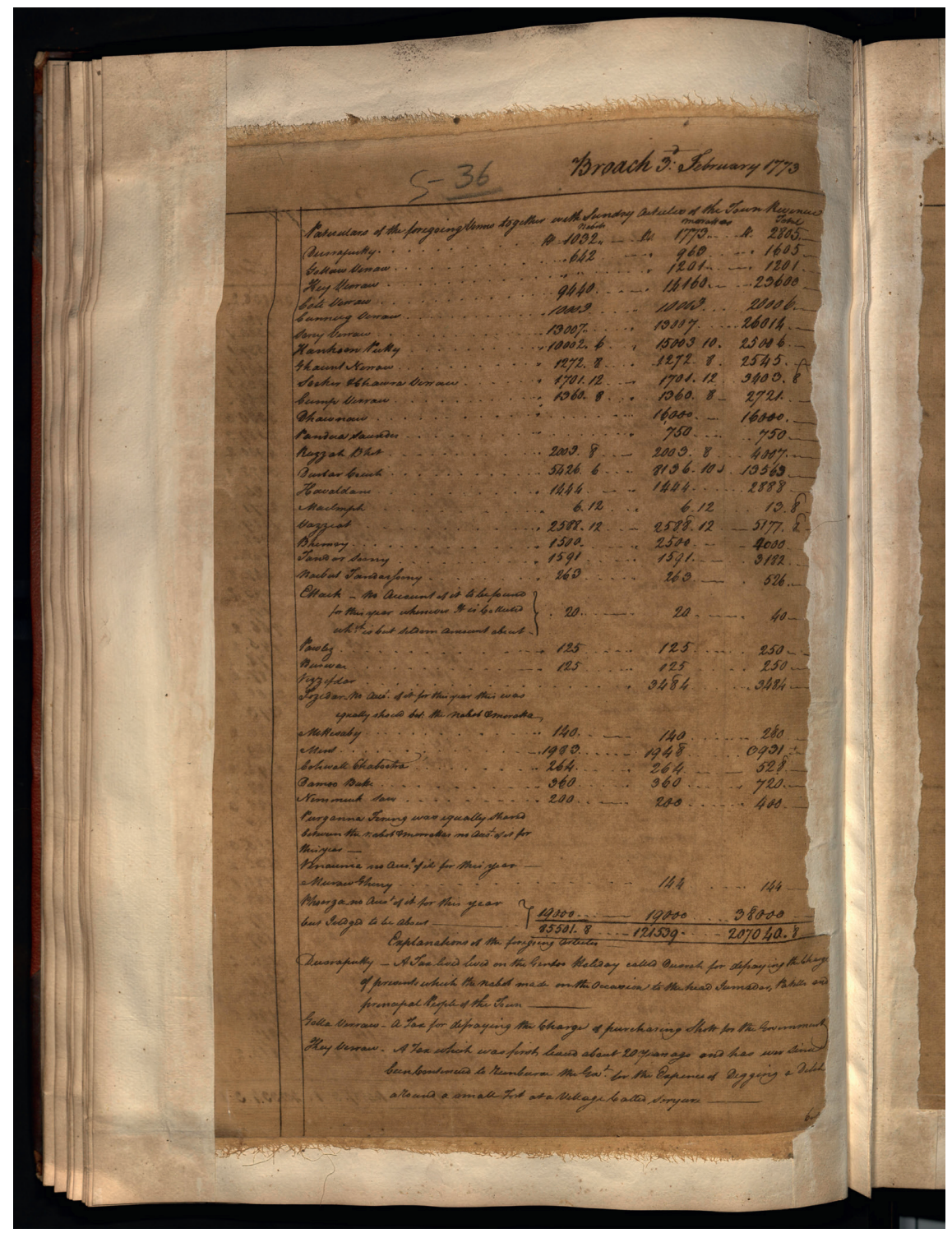

FIGURE 1

96 Morley, "Broach Revenues": f. 36. Columns containing figures for shares due to the "Nabob," the "Morattas," and the total amount are not included here. The "likely transcription" column represents my attempt to reconstruct Gujarati and Persian originals from Morley's list. 


\begin{tabular}{|c|c|c|c|}
\hline & $\begin{array}{l}\text { Particulars of } \\
\text { the verrow }\end{array}$ & $\begin{array}{l}{[\text { likely }} \\
\text { transcription] }\end{array}$ & [Morley's gloss] \\
\hline 1. & Dusraputty & $\begin{array}{l}{[G] \text { dasrā patțī }} \\
\text { દસરા પટ્ટી }\end{array}$ & $\begin{array}{l}\text { A Tax lived leved [sic] on the Gentoo } \\
\text { Holiday called Dusrah for defraying the } \\
\text { Charge of presents which the Nabob } \\
\text { made on the Occasion to the head } \\
\text { Jumadar, Patells and principal People of } \\
\text { the Town. }\end{array}$ \\
\hline 2. & Gollaw Verraw & $\begin{array}{l}{[G] \text { goḷā vero }} \\
\text { ગોળા વેરી }\end{array}$ & $\begin{array}{l}\text { A Tax for defraying the Charge of pur- } \\
\text { chasing Shott for the Government }\end{array}$ \\
\hline 3. & Key Verraw & $\begin{array}{l}{[G] \text { khāi vero }} \\
\text { ખાઈ વેરો }\end{array}$ & $\begin{array}{l}\text { A Tax which was first levied about } \\
20 \text { years ago and has ever since been } \\
\text { continued to reimburse the Govt for the } \\
\text { Expenses of Digging a Ditch around a } \\
\text { small fort at a Village called Soryare. }\end{array}$ \\
\hline 4. & Cote Verraw & $\begin{array}{l}{[\mathrm{G}] \text { khoț vero }} \\
\text { ખોટ વેરો }\end{array}$ & $\begin{array}{l}\text { A Tax levied the present year to make up } \\
\text { for any Deficiency which had happened } \\
\text { in the Revenue of the Former one ... } \\
\text { under the head of-[Cummy vero] }\end{array}$ \\
\hline 5 . & Cummy Verraw & $\begin{array}{l}{[\mathrm{p}, \mathrm{G}] \text { kamī vero }} \\
\text { કમી (ك) ) વેરો }\end{array}$ & $\begin{array}{l}\text { [contd. from Cote verraw] } \\
\text { The amount of which consequently dif- } \\
\text { fers annually }\end{array}$ \\
\hline 6. & Sony Verraw & $\begin{array}{l}\text { [G] sonī vero } \\
\text { સોની વેરો }\end{array}$ & $\begin{array}{l}\text { This was formerly levied only } \\
\text { Occasionally to furnish the Government } \\
\text { with a sum of money on any } \\
\text { Extraordinary Emergency but for the last } \\
14 \text { or } 15 \text { years it has been a Constant Tax } \\
\text { at the aforementioned Rate }\end{array}$ \\
\hline 7 . & Kankoon Putty & $\begin{array}{l}\text { [p, G] kānkūn } \\
\text { patțī કાનફૂન, } \\
\text { કારફૂન [نَرك] } \\
\text { પટ્ટી }\end{array}$ & $\begin{array}{l}\text { This was formerly levied by the Deshoy to } \\
\text { pay for Presents he gave annually to } \\
\text { the principal people of Government } \\
\text { to engage their Interest in his Favour. } \\
\text { But for several years past, the protection } \\
\text { thereof intended for those belonging to } \\
\text { the Nabob the latter carried to his own } \\
\text { account. }\end{array}$ \\
\hline
\end{tabular}


(cont.)
Particulars of
[likely
[Morley's gloss]
the verrow
transcription]

8. Ghaunsee

Verraw

A Tax for defraying the Government

Charge on purchasing Hay, but for some years past the Pragannahs were obliged to supply the nabob with as much of the article as he wanted for his Horses \& ca exclusive of paying the above mentd sum of money

9. Sooter \& [G] sūtar vero a Tax for paying the Govt Charges on Chawra Verraw સૂતર વેરો chāmḍā vero Thread [Sooter] \& Leather [Chawra] for saddles ચામડા વેરો

10. Cump Verraw ${ }^{97}$ [?] kamp vero કંપ વેરો

a Tax collected by the Moratta only for Gram \& Hay for their Horses

11. Dhawnaw [G] dhāno ધાનો or dāṇo દાણો

12. Pandria Saunder [G] Pandaria [?] પાંદરિઆ [?]

a Tax levied by the Morattas only to pay the Government Expences as a village called Padria

13. Ruzzah Bhet [p] raza bheț રઝા [^اء, rizāa'] ભેટ Harvest Season

14. Durbar Couch

[p] darbār A Tax for defraying Durbar Expences

kharch દરબાર ખર્ચ [دربار خرج]

15. Havaldaree

[p] havaldārī રવલદારી [حوال [دارى ] a Tax for paying the Expense of sending two Havaldars (one on the part of Nabob and the other on that of the Moratta) in a bad season to prevent the Farmer carrying off their Rice before they had paid the Government dues

97 Morley's gloss includes a tax not in his table, Cumess Verraw, which he explains as "a Tax for Joar \& Bajaree used by the Government." 
(cont.)

\begin{tabular}{|c|c|c|c|}
\hline & $\begin{array}{l}\text { Particulars of } \\
\text { the verrow }\end{array}$ & $\begin{array}{l}{[\text { likely }} \\
\text { transcription] }\end{array}$ & [Morley's gloss] \\
\hline 16. & Malmph & 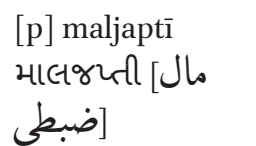 & $\begin{array}{l}\text { for the same purposes as the foregoing } \\
\text { [Havaldaree] on the other sort of Grain }\end{array}$ \\
\hline 17. & Vazzeat & $\begin{array}{l}\text { [p] vajīat વજીઅત } \\
\text { [وضشع] }\end{array}$ & $\begin{array}{l}\text { The amount of this was given to under } \\
\text { servants of the Durbar }\end{array}$ \\
\hline 18. & Bhunoy & [?] ભૂનીય & $\begin{array}{l}\text { a Tax levied on the Praganahs on a } \\
\text { Supposition of their paying bad money } \\
\text { at the Rate of } 4 \text { a Piece [ } 40 \text { Pice] for } 100 \\
\text { Rupees the good money is always taken } \\
\text { for them. }\end{array}$ \\
\hline 19. & Jaudar Soocry & $\begin{array}{l}\text { [p, G] jamādār } \\
\text { sukhḍī જમાદાર } \\
\text { [جعدار] સુખડી }\end{array}$ & $\begin{array}{l}\text { The produce of this was originally } \\
\text { intended to be given to the Jaudar as a } \\
\text { Reward for their services but in the latter } \\
\text { years the Nabob allowed them but a small } \\
\text { part of it and kept the Rest on his own } \\
\text { account }\end{array}$ \\
\hline 20. & $\begin{array}{l}\text { Naibut } \\
\text { Jaudarssoony } \\
\text { [soocry?] }\end{array}$ & 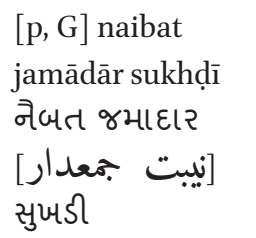 & $\begin{array}{l}\text { A Tax for Paying the Jaudar's deputies } \\
\text { who received the whole amount of it. }\end{array}$ \\
\hline 21. & $\begin{array}{l}\text { Ettack-No } \\
\text { account of it to } \\
\text { be found for this } \\
\text { year whenever } \\
\text { it is collected } \\
\text { which it is but } \\
\text { seldom arres- } \\
\text { cent about }\end{array}$ & [?] etak એટક & $\begin{array}{l}\text { a Tax for paying the Charges of } \\
\text { Sundry Sepoys to the Villages on any } \\
\text { Extraordinary Business. The amount } \\
\text { of this varies annually according to the } \\
\text { number of Sepoys so Employed }\end{array}$ \\
\hline 22. & Pawlez & $\begin{array}{l}\text { [p] pālez પાલેજ } \\
\text { ياليز }\end{array}$ & $\begin{array}{l}\text { a Tax on the Gardeners for Fruit \& } \\
\text { Vegetables }\end{array}$ \\
\hline 23. & Burwar & $\begin{array}{l}{[\mathrm{G}] \text { bharvāḍ }} \\
\text { ભરવાડ }\end{array}$ & A Tax on Goat Herds \\
\hline
\end{tabular}


(cont.)
Particulars of
[likely
[Morley's gloss]
the verrow
transcription]

24. Vizzefdar

[p] vajīfdār

A Tax levied by the Morrattas only on the وظيفه] دار

Villages which the Moguls King formerly granted for the support of some Mosques \& Religious Moormen

25. Fozedar-no

[p] fojdār ફોજદાર

Fines levied by the Government for

acct of it for this

[نوجدارى]

misdemeanours committed in the Broach

year this was

District

equally shared

betn the Nabob

and Moratta

26. Mottesaby

[p] mohtasabī

મોફતસબી

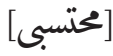

27. Mint [Tanksaul] [G] țanksāl ટંકસાલ

28. Cotwall

Chabootra

29. Dawroo Butte [arrack farm]

[G] kotvāl cabūtarā કોતવાલ ચબૂતરા

[p, G] dāru bhațhṭhī દારુ ભઠ્ઠી

3o. Nimmuck Saw

31. Purganna Fining was equally shared between the Nabob \& Morattas no acct of it for this year

[p] nimaksār مિમક સાર [مك سار] પરગણા [?]
Fee for chopping weight \& fixing the Door for a New House

The Government profit in Coinage which depending on the amount which may be Coined differs annually

See particular account thereof

This has lately been much more

Considerable having last year amounted to 2000 Rupees of which the Nabob paid the Moratta only 36o Rupees Produced by farming the Priviledge of making salt at Crodra a village at the Entrance of the River

[G, ?] pargaṇā Fines levied by the Jaudars in the Villages 
(cont.)

\begin{tabular}{|c|c|c|c|}
\hline & $\begin{array}{l}\text { Particulars of } \\
\text { the verrow }\end{array}$ & $\begin{array}{l}\text { [likely } \\
\text { transcription] }\end{array}$ & [Morley's gloss] \\
\hline 32. & $\begin{array}{l}\text { Vinaunia no } \\
\text { acct of it for this } \\
\text { year }\end{array}$ & [G] વિનોનિયો & $\begin{array}{l}\text { a present which the nabob received } \\
\text { from Cotton merchants from } 300 \text { to } \\
500 \text { Rupees per annum the Intention of } \\
\text { which was to prevent his taking notice } \\
\text { of their mixing seed in the Cotton. }\end{array}$ \\
\hline 33 . & $\begin{array}{l}\text { Muraw } \\
\text { [Menaw?] } \\
\text { Ghurry - }\end{array}$ & 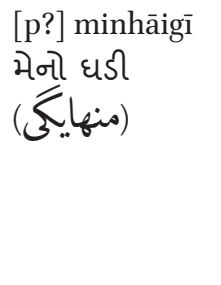 & $\begin{array}{l}\text { The Moody Collects } 18 \text { Rupees a } \\
\text { Month from the shopkeepers who sold } \\
\text { Medicines, Grain \&ca. of which the } \\
\text { Nabob received } 12 \text { Rupees. The Nabob } \\
\text { also collected a Tax under this name but } \\
\text { separately from the Nabob. }\end{array}$ \\
\hline 34. & $\begin{array}{l}\text { Phoorza no acct } \\
\text { of it for this year } \\
\text { but judged to be } \\
\text { about } \\
\text { TOTALS }\end{array}$ & $\begin{array}{l}{[p] \text { furza ફુરજા }} \\
{[\ddot{\omega} \dot{j}]}\end{array}$ & $\begin{array}{l}\text { the Custom Houses which included } \\
\text { Rodary, the Gauts Naukar \& Cooskey } \\
\text { Mandvie }\end{array}$ \\
\hline
\end{tabular}


Appendix 2: The Field Book of Kajipura, Pargana Matar, $1820^{98}$

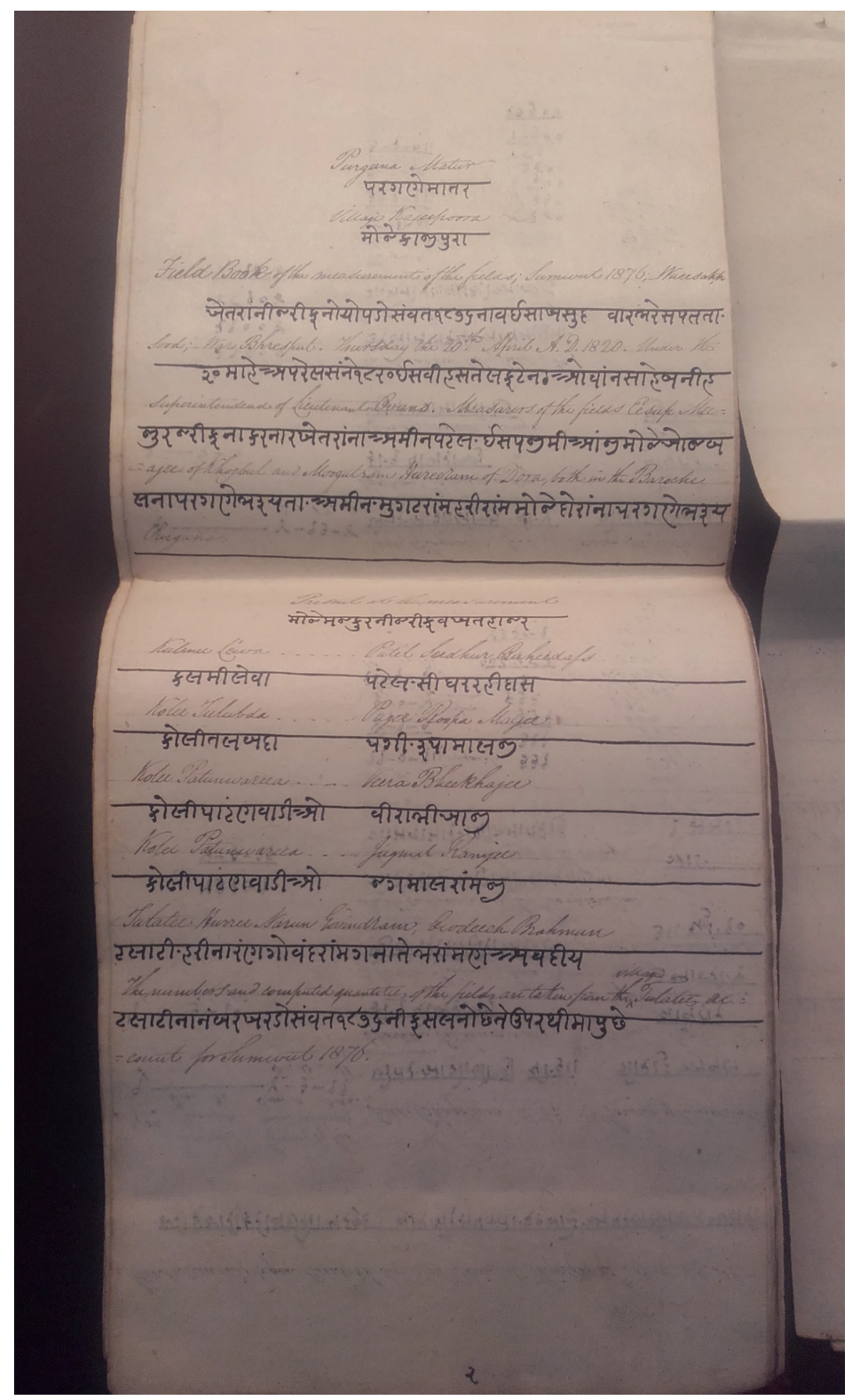

FIGURE 2

98 The field book is in Gujarati with interlinear translations in English. Here the first line will be Ovans' interlinear translation, followed by a transliteration of the Gujarati (Nagari) script, a Roman transcription of the Gujarati text, followed by (if Ovans' translation is 
f. 1a [a page of text in Nagari script, presumably in Gujarati, although only individual words can be made out. Not transcribed here.]

f. $\mathbf{1 b}$ [a page of text in Arabic, comprising verses attributed to 'Ali b. Abi Talib, al-Mutanabbi, the pre-Islamic poet Antara b. Shaddad, and an unidentified poet, written diagonally across the page. Not transcribed here. $\left.{ }^{99}\right]$

f. $2 a$

[In English] Purguna Matur

[Gujarati script] પરગણે માતર

[Transliterated from Gujarati] Pargaṇemātar

Village Kajeepoora

મોજે કાજીપુરા

Mojekājīpurā

[In English] Of this Book a duplicate is always found in which all the calculations are made by a Separate person, at a different time and by reversing the figures. This is done to verify the original. It is afterwards left at the village in the care of the people. The memorandum of the village Dara, or mode of collecting the government revenue-the Juma Khurch or account of village Receipts \& disbursements \& the Statement of the population are therefore not inserted in the duplicate.

\section{f. 3a-b Purguna Matur}

પરગણે માતર

Pargaṇemātar

Village Kajeepoora

મોજે કાજીપુરા

Mojekājīpurā

The Standard Basis, or Rod, is in length 5 Hath, or 8 feet English exactly. સરકારી વાંસલાં બામે ફાથ 5 પાંચ બરાબર છે તા ફીટ 8 આઠ અંગ્રેજી બરાબર છે

inaccurate or misleading), my own translation in italics. Until the mid-19th century, Gujarati was written with a superscript line which is not reproduced in my transliteration.

99 I am grateful to Ashkan Bahrani for transcribing and identifying the verses and to David J. Wasserstein for his comments. From occasional mistakes in the Arabic, it appears the scribe wrote them from memory. This presence of this Arabic page is not explained in the rest of the document. 
Sarkārī vāṃslāṃ bāme hāth 5 pāminch barābar chhe tā. [tathā] fịt 8 ățh angrejī barābar chhe

The government bamboo rods are exactly 5 hands or exactly 8 feet English.

All the measurements are made \& set down in Chains, Dusans [?] \& Hath સર્વે માપવાનુ કાંમ સાંકલ તા ગજ તા લીગ થી ચાલે છે Sarve māpvanu kām sānikal tā. gaj tā. līg thī chāle chhe All the measuring work is in chains and gaj and lig 100

One Chain contains 3 Dusans, and one Dusaus contains 10 Hath. સાંકલ 1 એક ના ગજ 3 તરણ છે ગજ 1 એક નાં લીગ 10 દસ છે Sānikal 1 ek nā gaj 3 taraṇ chhe gaj 1 ek nāṃ līg 10 das chhe One chain has 3 gaj and 1 gaj has 10 ligg

All the calculations are made in Hath સરવે ગણવાનુ કામ લીગથી ચાલે છે sarve gaṇvānu kām līgthī chāle chhe All measurements are in lig

25 Hath make one Wis-wussa. 500 Hath make one Wussa, and 10,000 લીગ પચીસનો વસવાંસી 1 એક છે લીગ 500 પાંચસે [સો] નો વસો 1 એક છે લીગ 10000 દસ ફજારનુ

līg pachīsno vasvāṃsī 1 ek chhe līg 500 pāñchse[so] no vaso 1 ek chhe līg 10000 das hajārnu 25 lìg make vasvāmisī. 500 lìg make 1 vaso. 10,ooo lìg make

Hath make one Beega, Square measure.

विद्यु 1 ओક छे

vīghu 1 ek chhe

ivighu [bigha]

Add the two perpendiculars together, multiply their sum by the diagonal આડી સાંકલ એકઠી કરવી ને લાંબી સાંકલ સાથે ભાંગણી કરવી ને તે āḍi sānkkal ekațhì karvī ne lāmbī sāṅkal sāthe bhāngaṇi karvī ne te Join the perpendicular chains and multiply the sum by the long chain and

$100 \quad$ See discussion of "lìg" in note 83 above. 
and half the product will be the contents of the figure in Hath.* નુ અડધ કરવું તેફેનાં વીદાં તા વસા તા વસવાંસી થાએ છે nu aḍadh karvu tehenāṃ vīghāṃ tā. vasā ta. vasvāṃsī thāe chhe halve it; that will be the bighā, vasa, vasvāa $\bar{\imath}$

In this Field Book the number \& contents of the field by the measurement એ જરીફના ચોપડામાં જરીફનો નમબર તા જરીફનાં વીઘાં ઉપર છે તા E jarîfnā chopaḍāmāṃ jarīfno nambar ta.[tathā] jarīfnāṃ vīghāṃ upar chhe ta.

In the Jarif book, the Jarif number is above the Jarif measurements in bigha

are placed above, and the number of the field \& its computed quantity by the village Tullatee's accounts, are placed below. તલાટીનો નમબર તા આસરાનો વીઘાં નીચે છે talāṭino nambar ta. āsrāno vīghāṃ nīche chhe The taläțìs number is below the estimated measurement in bighas.

[In English] * This is, of course, only applicable to the Trapezium, which is the figure always used with the exception of the Triangle occasionally.

\section{f. 4a-b Purguna Matur પરગણે માતર \\ Pargaṇe Mātar}

Village Kajeepoora

મોજે કાજીપુરા

Village Kājīpurā

Field Book of the measurements of the fields; Sumwut 1876, Wueesakh ખેતરાની જરીફનો ચોપડી સંવત 1876ના વૈસાખ સુદ વાર ભરેસ્પત તા khetarānī jarīfno chopaḍo samivat 1876 nā vaisākh sud vār bharespat tā. The book of the measurement of the fields (field book) [was done on] Thursday, of Vaisakh Sud, 1876 date

Sud; War Bhresput. Thursday the 2oth April AD 1820. Under the 20 માહે અપરેલ સનન 1820 ઈસ્વી इસતે લફ્ટેનઠ ઓવાન સાફેબની 20 māhe aparel sanne 1820 īsvī haste lafțenaṭ̆ ovān sāheb nī 20 [,] month of April year 1820 Christian [Era] at the hands of Lieutenant Ovan Saheb 
Superintendence of Lieutenant Ovans. Measurers of the fields Eesup Meeફજૂર જરીફના ખેતરાંના અમીન પટેલ ઈસપજી મીઆંજી મોજે ખોજબલ hajūr jarīf nā khetarāṃnā amīn pațel īsapjī mīāñjī moje khojbal [who was] present for the measurement of the fields Amin Patel Isapji Mianji of village Khojbal,

-ajee of Khojbul and Moogutram Hureeram of Dora, both in the Baroche ના પરગણે ભરૂચ તા. અમીન મુગટરામ ફરીરામ મોજે દોરાના પરગણે ભરૂચ na pargaṇe bharuch tā. amīn mugațrām harīrām moje dorānā pargaṇe bharuch district Bharuch and Amin Mugatram Hariram of village Dora, district Bharuch.

Present at the measurement

મોજે મજકુરની જરીફ વખત ફાજર

moje majkurnī jarîf vakhat hājar

Present at [the time of] the measurement of the aforesaid village

Kulmee Leuva Patel Seedhur Ruheedass

કલમી લેવા પટેલ સીધર રહીદાસ

kalamī levā patẹl sīdhar rahīdās

Kolee Tulubda Pugee Roopa Maljee

કોલી તલબદા પગી રૂપા માલજી

kolī talabdā pagī rūpāmāljī

Kolee Patunwareea Veera Bheekhajee

કોલી પાટણવાડીઓ વીરા ભીખાજી

kolī pāțanvāḍīo vīrā bhīkhāji

Kolee Patunwareea Jagmul Ramjee

કોલી પાટણવાડીઓ જગમલ રામજી

kolī pātạnvāḍīo jagmāl rāmjī

Tulatee Hurree Narun Govindram, Oodeech Brahmun તલાટી ફરી નારણ ગોવંદ રામ ગાનાતે ભરામણ અવદીચ țalāṭ̂ harī narạ̣ govand rām ganāte bharāmaṇ avadīch

The talāțì Hari Naran Govand Ram of the Audich Brahmin jati

The numbers and computed quantities of the fields are taken from the village Tulatees account for Sumvut 1876 તલાટીના નમબર ખરડો સંવત 1876ની ફસલની છે તે ઉપરથી માપુ છે 
țalāțīnā nambar kharḍo saṃvat 1876nī fasalno chhe te uparthī mapu chhe The taläțìs numbers and computed quantities are from the yield [fașal] of Samvat 1876 and are measured from them.

[f. 5a-36b are individual pages of measurements of individual fields, including information on zamindar, farmer, type of soil, what is grown, etc. One sample page is included here]

f. $5^{a}$

\begin{tabular}{|c|c|c|c|}
\hline & Field Bhagoleeoo & Bs. 5 & Goraroo of the first sorts \\
\hline \multirow{2}{*}{$3-4-17-4$} & ખેતર ભાગોલીઉ & वी. 5 & ગોરાડુ અવલ \\
\hline & Khetar bhāgolīu & Vì. 5 & Gorāḍu aval \\
\hline \multirow[t]{10}{*}{$3-5-0$} & [?] 1 Pokhreeoo, a day & & Crop \\
\hline & કી. 1 પોખરીઉ & & વાવેતર \\
\hline & Kī. 1 pokharīu & & vāvetar \\
\hline & Meeaa Peerbhaee & & 2B. Baota [?] 5 \\
\hline & મીઆં પીરભાઈ & & 2 બાવટી 5 \\
\hline & Mīāṃ Pīrbhāī & & 2 bāvțo 5 \\
\hline & & & $3^{B}$. Bajoree produced 1 1/2 \\
\hline & ખેડુત વીરાજી ભીખાજી & & 3 બાજરી 1 1/2 \\
\hline & Kheḍut Vīrājī Bhīkhājī & & 3 bājrī 1 1/2 \\
\hline & & & Mutt \& Mug? \\
\hline \multirow[t]{2}{*}{48611} & & & મઠ મગ o 1/2 \\
\hline & & & Math mag o $1 / 2$ \\
\hline \multicolumn{4}{|l|}{ 4-17-4 } \\
\hline & & & તલt 2 \\
\hline & & & Tal 2 \\
\hline & & & ઝાS \\
\hline & & & Jhāḍ \\
\hline & ઉપલા નમબરથી આથમણુ & & 1 મહુડી \\
\hline & Uplā nambarthī athamṇu & & 1 Mahuḍo \\
\hline & West from the number above & & 1 Mowra \\
\hline
\end{tabular}


તા ગોબલેજના સીમાડાથી

Tā goblej nā sīmāẹāthī

From the boundary of Goblej

(taluka?)

ઓતરાદુ તા. ઉગમણુ

Otarādu tā. ugamaṇu

North to east

[more measurements and calculations, not included]

[Note at the bottom, in English]: (See No. 79 for further translation. The above are considered sufficient for examples of the intermediate fields.)

f. 37 a Number 24 of o 1/2 Beega and Number 30 of 3 Beegas, of this Tulatee's account are

એ જમીનમાં તલાટીનો નમબર 24 ચોવીસમો વિદ્યુ ૦ ॥ મોજે ગોબલેજ સાથે e jamīnmāṃ talātịno nambar 24 chovīsmo vīghu o $\|(1 / 2)$ moje goblej sāthe In that land, half a bighà of the talätü's Number 24 and 2 bighäs of the taläțìs number 30 are in dispute with the village Goblej

in dispute with Goblej \& do not appear in this memorandum.

કચાટીઉ છે તેમાકુ નથી તા. તલાટીનો નમબર તીસમો વીઘા 2 મોજે ગોબલેજ સાથે કચાટીઉ છે તેમકુ નથી

kachāțīu chhe temaku nathī tā. talāțīno nambar 30 tīsmo vīghā 2 moje goblej sāthe kachāțīu chhe temaku nathī

and are not listed.

ff. 38-4oa columns of numbers

f. $4 \mathrm{ob}$ [Columns of measurements, not included.] [at bottom] 
Total of the area by the above figures

738-18-2 કુલ રકબો મોજે કાજીપુરાનો આ રકબો પેલી વખતની ગણલલ છે kul rakbo moje kājīpurāno ā rakbo pelī vakhat no gaṇelo chhe

Total of the area by a separate calculation in a duplicate field Book 736-7-8 કુલ રકબો મોજે કાજીપુરાનો આ રકબો બીજી વખતની ગણો છે kul rakbo moje kājīpurāno ā rakbo bījī vakhatno gạ̣o chhe

$1475-5-10$

737-12-15 કુલ રકબો મોજે કાજીપુરાનો

kul rakbo moje kājīpurāno

p. $41 \mathrm{a} 2-0-6$

7-2-6 ુરલ કચાટીઉ મોજે સમાદરા સાથે

kul kachātīu moje samādarā sāthe

Memorandum of the custom practised in this village of collecting the Government Revenue

īādās sarsatānī vīgoṭị vagarenā moje kājīpurāno

Rice ground is Bhagwutuee-or paying in Kind, કાએડાની ભાગબટાઈ હડધો ભાગ ખેડુની તા. ફડધો ભાગ સરકારનો kāeḍānī bhāgbaṭāī haḍdho bhāg kheḍuno ta. [tathā] haḍdho bhāg sarkārno The prevailing system of crop-sharing $[$ is $]$ half share to the farmer and half share to the government.

half is the Cultivator's and half goes to Government.

તા. કાઓડો ${ }_{1}$ વી 1. ઉધ્ધડ છે ર 3 લખેના છે જમીન ગોરાડુની વીઘો

tā. kāeḍo ivī. 1. ūdhaḍ chhe Ru 3 lakhenā chhe jamīn gorādunī vīgho and the prevailing system the first fallow/unmeasured is Rupees 3 [is written][.] Yellowish wet soil bigha land

There is one Beega let at a fixed rent of 3 Rupees an-

ટી દર વીઘે $1322 / 4$ પરમાણે નવુ ભાગે તેહેની વિઘીટી કાએડાની

țì dar vīghe 1 Ru 2 1⁄4 parmāṇe navu bhāge tehenī vīghoṭị kāeḍānī

-nually. Goraroo is Beegotee, or paying so much

વીઘે 1 ३ $21 / 4$ પરમાણે વરસ 5 સુધી એ પરમાણે ભરે તાર 5 છે

vīghe 1 Ru 2 1⁄4 parmāne varas. 5 sudhī e parmāṇe bhare tār 5 chhe 
p. Beega; here at the rate of $2 \frac{1 / 4}{4}$ Rupees. Goraroo made into Rice ground is Beegotee for 5 years at the rate ભાગ બટાઈ ફડધો ફડધ આપે bhāg bațāi haḍdho haḍadh āpe

of $21 / 4$ Rupees p. Beega, after which it becomes Bhag wuttaaee. Waste Goraroo taken into cultivation pays ગોરાડુ નવુ ભાગે તેફેની સાથ દર વીઘે 1 ર 11/2 પરમાણે પેફેલે વર gorādu navu bhāge tehenī sāth dar vīghe 1 Ru 1 1⁄2 parmāne pehele var

the first year 1 1/4 Rupee p Beega, and afterwards 2 1/4 Rupees p. Beega સ આપે તાર પછી ર $21 / 4$ પરમાણે ફર સાલ આપે s [varas] āpe tār pachhī Ru 2 1⁄4 parmāne har sāl āpe

Goraroo of an inferior kind (Kharor) when newly taken તા. ગોરાડુ ખારોડે મધે થી ભાગે નવી ભાગે તેડેની સાથ દર વીઘે 1 ta. gorāḍu khāroḍe madhe thī bhāge navī bhāge tehenī sāth dar vīghe 1

into cultivation, pays the first year $1 \mathrm{R}$ p. Beega \& [?] afterwards $11 \frac{1}{4} \mathrm{R} \mathrm{p}$. Beega annually.

રૂ લેખે પેફેલે વરસ આપે તાર પછી વી 1 ર 11/2 ફર સાલ આપે Ru 1 lekhe pehele varas āpe tār pachi vī 1 Ru 1 1⁄2 lekhe har sāl āpe

Memorandum of the Sulamee or payment to Government from land exempted from the regular assessment.

સલાંમીઆની ઈઆદાસ

salāmīānī îàās

Ghurreneea, or Mortgaged land, (one field only in this vill.) 1 1/2 Rup p. Beega

ઘરેણીઊ વી 4ની સલામી વી. 1 રૂ11/2= લેખે

ghareṇīu vì. 4 nī salāmī vī 1 Ru 1 1⁄2 = lekhe

A field of Hurrea (called Pussaeeta) or land given as a compensation for the loss of life in the cause of the village commons, 1 Rupee p Beega પસાઅતુ વી 6ની સલામી વી 1 રૂલેખે pasāatu vī 6 nī salāmī vī 1 Ru 1 lekhe

Memorandum of the Collections in aid of Govt from Irrigated Rice ground. The first or Rice crop is equally divided between the Cultivator and the Govern- 


\section{કુવેતર કાઓડો 1 સરકારીઓ છે તેમ ધે ડાંગરિ માં ભાગ ફડધ ફિડધ}

kuvetar kāeḍo 1 sarkārīo chhe tem ghe ḍāngari māṃ bhāg haḍadh hiḍadh

-ment, a deduction, however, being made previously to the division, of about $3 \mathrm{Rp}$
તા. જવ તા ધફુ તા વી ચીણો વગરેનો ચોથો ભાગ આપે
ta. jav tā. ghahu tā. 2 vī chịno vagareno chotho bhāg āpe

and given to Wuswaeeas or certain village servants. The second crop generally consisting of Barley, Wheat or Cheena, is Shared in the proportion ભાગ 1 સરકારમાં આપે તા. ભાગ 3 ખેડુના

bhāg 1 sarkār māṃ āpe ta. bhāg 3 kheḍunā

of three fourth to the cultivator and one fourth to the Government, without any deduction.

p. 41b Memorandum of the Pussaeeta and Chakureea, or land held for Service, to the village community. All free.

પસાઅતુ વગરે નકરૂ છે

pasāatu vagare nakaru chhe

Memorandum of the Veras or extra collections on account of Government ફલવેરો ફલ. 1 બલધ. 2 રૂ 2 લેખે તા. બલધ 1 ફોઅ તો રૂ1 પરમાંણે

halvero hal 1 baladh 2 Ru 2 lekhe tā. baladh 1 hoe to Ru. 1 parmāne

For every plough with two Bullocks 2 Rupees and with only one Bullock, 1 Rupee. The payment being made, the village is relieved from any requisition (Vit?)

આપે એ રૂપીઆ સરકાર અદાલત ની વેઠ છાંણા લાકડા તા. ઘાસનાં ગાડાં āpe e rupīā sarkār adālatnī vețh chhāṇā lākḍā tā. ghāsnā gādā

of the Adaulut for Chaua (dried cowdung cakes for fuel). Firewood and બાબત લે છે એ રૂપીઆ આપીએ છઈએ તારે વેઠ માપ છે એ સવાએ bābat le chhe e rupiāa āpīe chhīe tāre vethe māp chhe e savae

Grass. There is no other Vera or Collection of any kind in this village. બીજી કંઈ પેદાસ તા. વેરો નથી

bījī kaī pedās tā. vero nathī

1 Patel Sīdhardās Rahīdās 
1 પટેલ. સીધરદાસ રફીદાસ

ઉપર લખા પરમાંણે સહી

upar lakhā parmāne sahī

As written above

Talāțī Harnārāeṇ Govind Rām

તલાટી ફરનારાએણ ગોવિંદ

રાંમ ઉપર લાખ પરમાંણે સહી

rām ūpar lakhā parmāṇe sahī

As written above

[Signature of the Principal Patel and Village Tulatee]

Memorandum of the Village Tulatee's Numoonus, or Statements of the [?] for Sumvut 1876

ઈઆદાસ મોજે કાજીપુરા પરગણે માતર ના ગામ સંવત 1876 ની ફસલની નમુની īādās moje kājīpurā pargaṇe mātar nā gām saṃvat 1876 nī fasal no namuno

[More measurements of the arable land and other village characteristics; not included.]

f. 42a-b [List of all cultivable land, waste land, well, pond, etc. with totals. Not included here]

f. 43a The Juma Khurch, or Account of receipts, and disbursements, of the village of Kajeepoora, Matur Puga. for the Season of Sumvut 1875

મોજે કાજીપુરાનો જમે ખરચ પરગણે માતરના ગામાનો સંવત 1875 ની ફસલની

moje kājīpurāno jame kharach pargaṇe mātarnā gāmāno saṃvat 1875 nī fasalno

ॐ

om

[Calculations, not included here]

\section{f. 44a blank}

f. $45^{a-45}$ Statement of the population of the village of Kajeepoor. Sumvut 1876 Waesakh. April AD 1820 
ખરડો કુલ વસતી નો માણસ તથા જાનવરનો મોજે કાજીપુરાનો સંવત 1876ના વૈસાખ માંહે

Kharḍo kul vasatĩ no māṇas tathā jānvar no moje kājīpurāno saṃvat 1876 nā vaisākh māhe āparel sane 1820

[Table with 10 columns displaying headers as below]

Gāmnī vasatīnī jāt ગામની વસતીની જાત The jāti of the village's population

Ghar ધર Homes

Marad tā chhokrā મરદ તા. છોકરા Men and boys

Orat tā chhokrī ઓરત તા. છોકરી Women and girls

Kul māṇas કુલ માણસ Total humans

Baladh tā vāchhaḍo બલધ તા. વાછડો Oxen and male calves

Gāa tā vāchhaḍī ગાઆ તા. વાછડી Cows and female calves

Bheso tā pāḍo ભેસો તા. પાડો Buffaloes and calves

Gāḍā JIsı Carts

Hol હોલ Ploughs

[46 Rows listing each household head, arranged into jāti groups as below. Names and numbers not included here.] કલમી લેવા, કોલી તલબદા, કોલી પાટણવાડીઆ, વસવાઆ

Kalamī levā; Kolī talabdā; Kolī pāṭaṇvāḍīa, vasvāā

f. 46a [Tallied totals of the census, listing 46 households, 79 men and boys, 74 women and girls, 153 persons in total, 43 bullocks and bull calves, 12 cows and female calves, 34 buffaloes and calves, 7 carts, and 16 1/2 ploughs.]

f. 47a The general Acknowledgement and Receipt

ઈઆદાસ ફારગતીની

iādās fāragatīnī

We the undersigned Patell, and Tulatee of the village of Kajeepoora લા. અમે પટેલો તા. તલાટી મોજે કાજીપુરાનાં ખેતરો તા. જમીન દેખાડીને lā. ame pațelo tā. talāṭi moje kājīpurānā khetaro tā. jamīn dekhādīne

declare that we pointed out the field, and lands of our village and were present at their measurement.

ભરાવીને ભરતી વખત ફાજર ફતા જત [જન ?]

bharāvī ne bhartī vakhat hājar hatā jat 
Likewise, that we paid the field measurer સરકારી જરીફના કરનારને ભાથાના ખરચના પઈ sarkārī jarīfnā karnārne bhāthā nā kharcha paī

their Batta as ordered by Government, and nothing more or less સા સરકારના હુકંમ પરમાંણે આપા છે ને ફુકંમ સવાએ એક દમડી જાદા તા. કંમ sā [paisa] sarkārnā hukam parmāṇe āpā chhe hukam savae ek damḍi jāda tā kam

was given or received.

આપી લીધી નથી

āpī līdhī nathi.

Whatever was taken at the village by the સાહેબના ખરચ વગેરે ને વાસતે જે સાંમંન લીધો

Sāhebnā kharach vagere ne vāste je sāman līdho

Superintending Officer or by any of his servants, whether from આ પોતેના પઈસા તા. નોકર ચાકર લોકના ખરચ ખુરાકી વગરે જે કંઈ વાંણી āpo tenā paisā tā. nokar chākar loknā kharach khurāki vagere je kaī vāṇī

the Buneea or from any other person belonging to the village આને તાંહાંથી તા. ગાંમમાંથી લીધુ ફસે તે સરવે ના પઇસા દાંમ દરમ દરોબસત ફ āne [vaṇiāne] tāhāthī tā. gām māṃthī līdhu hase te sarve nā paisā dām daram darobast ha-

has been duly paid for to the people themselves to the village સાબ ફારીન વાલી લીધા વહે ફાવે થી એ જરીફના કાંમ સમંધીનુ લેવુ દેવું કોઈ જોડે -sāb karīne vālī līdhā chhe hāve thī e jarīfnā kām samandhīnu levu devu koi joḍe

[and something] and [?] on accounts of this measurement રફુ નથી ને ફસાબ વાલી લેઇ ને ફારગતી લખી આપી છે એ લખુ સફી સંવત 18 rahu nathi ne hasāb vālī leine fāragatì lakhī āpī chhe e lakhu sahī saṃvat 18

nothing whatever remains [unstated?] and this acquittance is 76 ના પેરેલા જેઠ વાળ 5 વાર. ગરે ઊ તા. 1 માહે જુન સને 1820 ઈસવી 76 nā pahela jețh vad 5 vār gareū tā. 1 māhe jun sane 1820 îsvī given accordingly. Sumwut 1876, 7 th Jeth wud 5 th Thursday 1st June AD 1820 
Patell Seedhur Ruheedas

1 પટેલ સીધરદાસ રહિદાસ ઊ

1 Patel Sīdhardās Rahīdās

The above writing is the truth

પર લખુ તે સહી છે

ūpar lakhu te sahī chhe

Tulatee Hur Narain Govind Ram

1 તલાટી ફારનારાએણ ગોવંદરાં

1 Talāțị Harnārāeṇ Govandrām

The above writing is the truth

મ ઉપર લખુ તે સફી છે

upar lakhu te sahi chhe

\section{Acknowledgments}

For comments on this paper I am grateful to the participants in "Transactions and Documentation in the Persianate world," a workshop of the Lawforms project, Exeter (July 2018), "New Directions in South Asian Economic History," a workshop at the University of Pennsylvania (May 2019), and to three anonymous reviewers and the editing staff at JESHO. Thanks especially to Ashkan Bahrani, Nandini Chatterjee, Faisal Chaudhry, Divya Cherian, Sumit Guha, Najaf Haider, Prashant Kidambi, Françoise Mallison, Dipanjan Mazumder, Sudev Sheth, Amrita Shodhan, Ramya Sreenivasan, Musa Subramaniam, Elizabeth Thelen, David J. Wasserstein, Dominic Vendell, and Steven Vose for their help. All errors remain mine. I thank the European Research Commission and the Lawforms project for providing funds to publish this article, and the entire issue, in Open Access format.

\section{Bibliography}

\section{Unpublished Sources}

Surat Factory Diaries. Mumbai: Maharashtra State Archives.

Broach Factory Diaries. Mumbai: Maharashtra State Archives.

Revenue Department Diaries, Mumbai: Maharashtra State Archives. 1785. Haqüqat-i Bandar Bharūch. Oxford: Bodleian Library.

1820. Jarîf-No Chopḍo (Measurement Papers and Records of the Village of Kājipurā,

Parganah Mātar, in the Broach District of Bombay). Oxford: Bodleian Library. 


\section{Published Sources}

1845. Debates at the India House: August 22nd, 23rd and September 14th, 1845, on the Case of the Deposed Raja of Sattara and the Impeachment of Col. C. Ovans. London: Effingham Wilson.

Abbott, N.J. 2018. Bringing the Sarkār Back In: Translating Patrimonialism and the State in Early Modern and Early Colonial India. In State Formations: Global Histories and Cultures of Statehood, ed. J.L. Brooke, J.C. Strauss and G. Anderson. Cambridge, Cambridge University Press: 124-137.

Abu'l Fazl. 1891. Á'̄n-i Akbarī, trans. H.S. Jarrett, 2 vols. Calcutta: Asiatic Society of Bengal.

Alam, Muzaffar and Sanjay Subrahmanyam. 2004. The Making of a Munshi. Comparative Studies of South Asia, Africa and the Middle East 24/2: 61-72.

Alam, Muzaffar and Sanjay Subrahmanyam. 2010. Witnesses and Agents of Empire: Eighteenth-Century Historiography and the World of the Mughal Munshī.Journal of the Economic and Social History of the Orient 53/1-2: 393-423.

Alam, Muzaffar. 1998. The Pursuit of Persian: Language in Mughal Politics. Modern Asian Studies 32/2: 317-49.

Alam, Muzaffar. 2003. The Culture and Politics of Persian in Precolonial Hindustan. In Literary Cultures in History: Reconstructions from South Asia, ed. Sheldon Pollock. Berkeley: University of California Press: 131-98.

Alam, Muzaffar and Seema Alavi. 2001. A European Experience of the Mughal Orient: The I'jāz-i Arsalānī (Persian Letters 1773-1779) of Antoine-Louis Henri Polier. New York: Oxford University Press.

Anooshahr, A. 2012. Author of One's Fate: Fatalism and Agency in Indo-Persian Histories. Indian Economic and Social History Review 49/2: 197-224.

Asani, A.S. 1987. The Khojkī Script: A Legacy of Ismaili Islam in the Indo-Pakistan Subcontinent. Journal of the American Oriental Society 107: 439-49.

Bagheri, M. 1998. 'Siyāqat' Accounting: Its Origin, History, and Principles. Acta Orientalia Academiae Scientiarum Hungaricae 51: 287-301.

Bayly, C.A. 1996. Empire and Information:Intelligence Gathering and Social Communication in India, 1780-1870. Cambridge: Cambridge University Press.

Bellenoit, Hayden. 2014. Between Qanungos and Clerks: The Cultural and Service Worlds of Hindustan's Pensmen, c. 1750-185o. Modern Asian Studies 48/4: 1-39.

Bellenoit, Hayden J. 2017. The Formation of the Colonial State in India: Scribes, Paper and Taxes, 1760-1860. London and New York. Taylor \& Francis.

Belsare, M.B. 1993. An Etymological Gujarati English Dictionary. New Delhi: Asian Educational Services.

Bhadani, B.L. 1999. Peasants, Artisans and Entrepreneurs: Economy of Marwar in the Seventeenth Century. Delhi: Rawat Publications. 
Bhagvatsiṃhīī and Candulāl Pațel. 2008 (original publication 1944-55). Bhagavadgomaṇdal. Rajkot: Pravịn Prakāśan. (GujaratiLexicon.com).

Chatterjee, Kumkum. 20o9. The Cultures of History in Early Modern India:Persianization and Mughal Culture in Bengal. Delhi: Oxford University Press.

Chatterjee, Nandini. 2020. Negotiating Mughal Law: A Family of Landlords Across Three Indian Empires. Cambridge: Cambridge University Press.

Cherian, Divya. 2015. Ordering Subjects: Merchants, the State, and Krishna Devotion in Eighteenth-Century Marwar. Ph.D. dissertation: Columbia University.

Clark, Alice. 1976. Changes in Kinship and Marriage in Two Selected Areas in India: A Study Based on Female Infanticide Records During the Nineteenth Century. Ph.D. thesis: University of Delhi.

Cohn, Bernard S. 1959. Some Notes on Law and Change in North India. Economic Development and Cultural Change 8: 79-93.

Cohn, Bernard S. 1996. Colonialism and Its Forms of Knowledge: The British in India. Princeton, N.J.: Princeton University Press.

Curley, David L. 2020. Styles of Mastery of a Calcutta Brahman Family: Krishnachandra Ghoshal's Pilgrimage to Gaya, Kashi and Prayag, 1769, in Vijayram Sen's Tirthamangala. The Indian Economic and Social History Review 57/1: 77-123.

Dalrymple, William, ed. 2019. Forgotten Masters: Indian Painting for the East India Company. London: The Wallace Collection.

Deshpande, M.M. 1993. Sanskrit \& Prakrit: Sociolinguistic Issues. Delhi: Motilal Banarsidass.

Deshpande, M.M. 2008. Sanskrit in the South Asian Sociolinguistic Context. In Language in South Asia, edited by B.B. Kachru, Y. Kachru, S.N. Sridhar. Cambridge: Cambridge University Press.

Dirks, Nicholas. 1986. From Little King to Landlord: Property, Law, and the Gift under the Madras Permanent Settlement. Comparative Studies in Society and History 28/2 (1986): 307-33.

Dixit, Yatindra I. 1988. The Legal Documents (Khatapatras): A Study of the SocioEconomic Life of Ahmedabad Based on Original Gujarati Documents. Journal of the Oriental Institute 38: 73-8.

Eaton, Richard M. 2014. The Rise of Written Vernaculars: The Deccan, 1450-1650. In After Timur Left: Culture and Circulation in Fifteenth-Century North India, ed. Francesca Orsini and Samira Sheikh. New Delhi: Oxford University Press.

Forbes, James. 1813. Oriental Memoirs: Selected and Abridged from a Series of Familiar Letters Written During Seventeen Years Residence in India: Including Observations on Parts of Africa and South America and a Narrative of Occurrences in Four India Voyages, vol. 3. London: White, Cochrane, and Co. 
Forrest, George W. ed. 1887. Selections from the Letters, Despatches, and Other State Papers, Preserved in the Bombay Secretariat, vol. 2, Home Series. Bombay: Government Central Press.

Frost, Marcia J. 2000. Coping with Scarcity: Wild Foods and Common Lands: Kheda District (Gujarat, India), 1824/5. Indian Economic and Social History Review 37/3: 295-329.

Green, Nile. 2019. The Persianate World: The Frontiers of a Eurasian Lingua Franca. Berkeley, University of California Press.

Grover, B.R. 1961. The Position of Desai in the Pargana Administration of Subah Gujarat under the Mughals. Proceedings of the Indian History Congress 24: 150-5.

Guha, Sumit. 2003. The Politics of Identity and Enumeration in India c. 160o-199o. Comparative Studies in Society and History 45/1: 148-67.

Guha, Sumit. 2004. Transitions and Translations: Regional Power and Vernacular Identity in the Dakhan c. 1500-180o. Comparative Studies of South Asia, Africa and the Middle East 24/2: 23-31.

Guha, Sumit. 2010. Serving the Barbarian to Preserve the Dharma: The Ideology and Training of a Clerical Elite in Peninsular India c. 1300-1800. The Indian Economic and Social History Review 47/4: 497-525.

Guha, Sumit. 2015. Rethinking the Economy of Mughal India: Lateral Perspectives. Journal of the Economic and Social History of the Orient 58/4: 532-75.

Habib, Irfan. 1996. A Documentary History of the Gosā'in of the Chaitanya Sect at Vrindāvan. In Govindadeva: A Dialogue in Stone, ed. M. Case. New Delhi, Indira Gandhi National Centre for the Arts: 131-59.

Habib, Irfan. 2000. The Agrarian System of Mughal India, 1556-1707. New Delhi: Oxford University Press.

Haider, Najaf. 2011. Norms of Professional Excellence and Good Conduct in Accountancy Manuals of the Mughal Empire. International Review of Social History 56: 263-74.

Haider, Najaf. 2014. Language, Caste and the Secretarial Class in Mughal India. In The Evolution of a Nation Pre-Colonial to Post-Colonial: Essays in Memory of R.S. Sharma, ed. D.N. Jha. Delhi: Manohar: 249-62.

Hariharan, Shantha. 2003. Town Revenues and Taxes in Eighteenth Century Gujarat: An English East India Company Document. South Asia Research 23/2: 171-9.

Hasan, Farhat. 2004. State and Locality in Mughal India: Power Relations in Western India, c. 1572-1730. Cambridge: Cambridge University Press.

Hasan, Farhat. 2018. Property and Social Relations in Mughal India: Litigations and Disputes at the Qazi's Court in Urban Localities, 17th-18th Centuries. Journal of the Economic and Social History of the Orient 61/5-6: 851-77.

Hirschler, Konrad. 2016. From Archive to Archival Practices: Rethinking thePreservation of Mamluk Administrative Documents. Journal of the American Oriental Society 136/1: 1-28. 
Khān, 'Ali Muḥammad and Mīṭhālāl Kāyasth. 1928. Mir'āt-i Ahmmadī: Supplement. Translated by S. Nawab Ali and C.N. Seddon. Baroda: Oriental Institute.

Khān, 'Ali Muḥammad and Mịthālāl Kāyasth. 1930. Khātima-yi Mir'āt-i Aḥmadī, ed. S. Nawab Ali. Baroda: Oriental Institute.

Khān, 'Ali Muḥammad. 1926-3o. Mir'āt-i Aḥmadī, ed. S. Nawab Ali. Baroda: Oriental Institute.

Khān, 'Ali Muhammad. 1965. Mir'āt-i Aḥmadī. A Persian History of Gujarat. Translated by M.F. Lokhandwala. Baroda: Oriental Institute.

Khan, Shaukatullah. 1998. An Important Persian Source on Mughal Gujarat-Diwanu Khatanu Pustak. Historicus: Journal of Pakistan Historical Research 46: 49-59.

Kinra, Rajeev. 2015. Writing Self, Writing Empire: Chandar Bhan Brahman and the Cultural World of the Indo-Persian State Secretary. Berkeley: University of California Press.

Lhost, E. 2018. Writing Law at the Edge of Empire: Evidence from the Qazis of Bharuch (1799-1864). Itinerario 42/2: 256-78.

Majumdar, A.K. 1956. The Chaulukyas of Gujarat. Bombay: Bharatiya Vidya Bhavan.

Mehta, Makrand. 1981. Khatapatras as a Source of Urban History. Indian Archives 3o: 21-9.

Miller, Christopher Ray. 2014. Devanagari's Descendants in North and South India, Indonesia and the Philippines. Writing Systems Research 6/1: 10-24.

Misra, S.C. 1963. The Rise of Muslim Power in Gujarat. London: Asia Publishing House.

Misra, S.C. 1982. Some Aspects of the Economy of the Sultanate of Gujarat. Proceedings of the Indian History Congress 43: 243-59.

Mohiuddin, M. 1971. The Chancellery and Persian Epistolography under the Mughals, from Babur to Shah Jahan, 1526-1658. Calcutta: Iran Society.

Moir, M. and L. Zastoupil, ed. 1995. The Great Indian Education Debate: Documents Relating to the Orientalist-Anglicist Controversy, 1781-1843. Richmond: Curzon.

Munshī, Kishor Dās. 1957. Majmu'a-yi Dānish (Majmua-E-Danish: Life and Time of Kishore Das Munshi from 1740-1780), ed. S. Maqbul Ahmad, partial trans. Saeed Hasan. Allahabad: Bharatiya Vidya Bhawan, Bombay, Ram Narain Lal.

O'Hanlon, Rosalind. 2010. The Social Worth of Scribes: Brahmins, Kāyasthas and the Social Order in Early Modern India. The Indian Economic and Social History Review 47/4: 563-95.

Orsini, Francesca. 2015. The Multilingual Local in World Literature. Comparative Literature 67/4: 345-74.

Peabody, Norbert. 2001. Cents, Sense, Census: Human Inventories in Late Precolonial and Early Colonial India. Comparative Studies in Society and History 43/4: 819-50.

Pedder, W.G. 1895. Papers Relating to the Settlement of the Hereditary District Officers' Watan in the Deccan and Gujarat. Bombay: Government Central Press. 
Prior, K., L. Brennan, and R. Haines. 2001. Bad Language: The Role of English, Persian and Other Esoteric Tongues in the Dismissal of Sir Edward Colebrooke as Resident of Delhi in 1829. Modern Asian Studies 35/1: 75-112.

Rabitoy, Neil. 1975. System v. Expediency: The Reality of Land Revenue Administration in the Bombay Presidency, 1812-1820. Modern Asian Studies 9/4: 529-46.

Rahman, T. 1999. Decline of Persian in British India. South Asia: Journal of South Asian Studies 22/1: 47-62.

Raman, Bhavani. 2012. Document Raj: Writing and Scribes in Early Colonial South India. Chicago: University of Chicago Press.

Richards, J.F. 1986. Document Forms for Official Orders of Appointment in the Mughal Empire: Translation, Notes and Text. Cambridge: E.J.W. Gibb Memorial Trust.

Richards, J.F. 1993. The Mughal Empire. Cambridge: Cambridge University Press.

Sahai, Nandita Prasad. 2006. Politics of Patronage and Protest: The State, Society, and Artisans in Early Modern Rajasthan. New Delhi: Oxford University Press.

Scott, James C. 1998. Seeing Like a State: How Certain Schemes to Improve the Human Condition Have Failed. New Haven: Yale University Press.

Shafi, M.M. 1936. Three Old Documents. Proceedings of the Idara-yi Ma'arif-i Islamia, Lahore: $281-5$.

Shah, A.M., R.G. Shroff, and A.R. Shah. 1963. Early Nineteenth Century Village Records in Gujarat. Gujarāta Saṃśodhana Maṇdalanum Traimāsika:Journal of the Gujarat Research Society 25:126-34.

Sharma, G.D. 1984. Economy and Society of Rural Gujarat in the Second Half of the 18th Century: A Study based on the Haribhakti Papers. Proceedings of the Indian History Congress 45: 367-74.

Sharma, G.D. and Jaspal Kaur Dhot. 1985. Marathi Records on the State Revenue in Gujarat During the Second Half of the Eighteenth Century. Indian Historical Records Commission: 83-98.

Sharma, G.D. and M.A. Patel. State and Indigenous Business in the Urban Economy of Gujarat, c. 1770-1810: A Study of the Haribhakti Records. In Urbanization in Western India, ed. Makrand Mehta. Ahmedabad: Gujarat University: 59-71.

Sheikh, Samira. 2014. Languages of Public Piety: Bilingual Inscriptions from Sultanate Gujarat, c. 1390-1538. In After Timur Left: Culture and Circulation in Fifteenth-Century North India, ed. Francesca Orsini and Samira Sheikh. New Delhi: Oxford University Press: 186-212.

Sheikh, Samira. 2017. Jibhabhu's Rights to Ghee: Land Control and Vernacular Capitalism in Gujarat, circa 1803-10. Modern Asian Studies 51/2: 350-74.

Shelat, Bharati. 2012. The Gujarati Stone Inscriptions from Rās Howlef (Socotra). In Foreign Sailors on Socotra: The Inscriptions and Drawings from the Cave Hoq, ed. Ingo Strauch. Bremen: Hempen Verlag: 407-32. 
Sheth, Sudev. 2018a. Business Households, Financial Capital, and Public Authority in India, 1650-1818. Ph.D. dissertation: University of Pennsylvania.

Sheth, Sudev. 2018b. Revenue Farming Reconsidered: Tenurial Rights and Tenurial Duties in Early Modern India, ca. 1556-1818. Journal of the Economic and Social History of the Orient 61/5-6: 878-919.

Sikandar b. Muhammad. 1961. Mir'at-i Sikandarī, ed. S.C. Misra. Baroda: M.S. University of Baroda.

Srivastava, Surabhi. 2014. Fiscal Terms in Western Chaulukya Testimony. Proceedings of the Indian History Congress 74: 1387.

Strauch, Ingo. 2002. Die Lekhapaddhati-Lekhapañcāśikā: Briefe und Urkunden im mittelalterlichen Gujarat: Text, Übersetzung, Kommentar: Glossar (Sanskrit-DeutschEnglisch). Berlin: D. Reimer.

Subrahmanyam, Sanjay, and C.A. Bayly. 1988. Portfolio Capitalists and the Political Economy of Early Modern India. Indian Economic and Social History Review 25/4: 401-24.

Travers, Robert. 2007. Ideology and Empire in Eighteenth-Century India: The British in Bengal. Cambridge: Cambridge University Press.

Williams, Monier. 1825. Memoir on the Zilla of Baroche; Being the Result of a Revenue, Statistical, and Topographical Survey of that Collectorate; Executed by Order of the Bombay Government. London: Cox and Baylis.

Wilson, H.H. 1855. A Glossary of Judicial and Revenue Terms, and of Useful Words Occurring in Official Documents Relating to the Administration of the Government of British India from the Arabic, Persian, Hindustání, Sanskrit, Hindí, Bengálí, Uriya, Maráți, Guzaráthí, Telugu, Karnáta, Tamil, Malayálam, and Other Languages. London: Wm. H. Allen \& Co. 